\title{
La Semana Santa y la recatolización de Huelva. Un acercamiento a la construcción simbólica del franquismo de posguerra
}

\author{
Semana Santa and Re-catholization in Huelva. An Approach \\ to the Symbolic Construction of Early Francoism
}

\author{
José Carlos Mancha Castro \\ Universidad de Sevilla \\ jose.mancha@pi.uhu.es \\ ORCID: 0000-0003-0092-4417
}

Recibido: 22-11-2017

Aceptado: 27-02-2018

Cómo citar este artículo / Citation: MANCHA CASTRO, José Carlos. La Semana Santa y la recatolización de Huelva. Un acercamiento a la construcción simbólica del franquismo de posguerra. Pasado y Memoria. Revista de Historia Contemporánea, 17, pp. 413-452. https://doi.org/10.14198/PASADO2018.17.15

\section{Resumen}

El presente trabajo aborda una aproximación a la Semana Santa de Huelva durante los años más intensos del proyecto de 'recatolización' llevado a cabo en la ciudad por las autoridades franquistas y la jerarquía de la Iglesia católica. La Semana Santa onubense fue utilizada para la creación y reproducción -a través de sus símbolos- de un imaginario memorialista sobre el período republicano y la guerra, y para la socialización en los valores y las ideologías del régimen naciente, fusionando en el ceremonial público liturgias militaristas, fascistas falangistas y nacional-católicas. La fiesta, resignificada como un evidente rito de victoria, aunó -en sus complejos rituales- símbolos referentes a las diferentes construcciones ideáticas de los grupos políticos que compusieron el régimen franquista. Sus cortejos mostraron una sinergia, una comunión pública, entre la jerarquía eclesiástica y las distintas autoridades cívico-militares, aunque esos poderes persiguieran fines diferentes.

Palabras clave: Primer franquismo. Cofradías. Religiosidad popular. Huelva. Semana Santa. 


\begin{abstract}
This paper deals with an approach to Huelva's Semana Santa during the most intense years of the 're-catholization' project in Francoism. Said project was carried out in the city by Francoist authorities and the hierarchy of the Catholic Church. Huelva's Semana Santa was used for the creation and reproduction -by means of its symbolsof a memorial imaginary about the republican period and the Civil War. It was also used to foster the spread and acceptance of the newly born regime values and ideology, fusing military, fascist, Falangist and national-Catholic liturgies in public ceremonials. This performance, reinterpreted as an evident rite of victory, combined -in its complex rituals- symbols of the different ideological constructions of Francoist regime political parties. Its entourages displayed synergy, public communion, between the Church hierarchy and the different civic and military authorities, even though each of those sectors intended different purposes.
\end{abstract}

Keywords: Early Francoism. Cofradías. Popular religiosity. Huelva. Semana Santa.

\title{
1. Introducción
}

Desde la década de los ochenta del siglo pasado se han intensificado los estudios históricos y antropológicos sobre rituales y fiestas populares en Andalucía. Estos fenómenos han sido definidos como expresiones de la vida social en el plano de lo simbólico, reveladoras de aspectos centrales de la estructura social y la cultura que las organiza y celebra. Constituyen un lenguaje sobre la realidad por el que transitan mensajes ideáticos y emotivos de carácter polisémico que cobran sentido en el seno del abecedario cultural del pueblo en el que tienen lugar ${ }^{1}$.

Las fiestas no son celebraciones inalterables en el tiempo, ni rituales herméticos - puros- provenientes de códigos tradicionales que han sobrevivido, de manera inmutable, a la modernidad. Las fiestas se han transformado, (re)inven$t_{a d o}{ }^{2}$, a la vez que han cambiado los factores sociales, políticos, económicos

\footnotetext{
${ }^{1}$ Para atender al estudio de las fiestas y rituales andaluces desde una perspectiva antropológica, resulta imprescindible atender al marco teórico-metodológico que ofrecen Moreno Navarro y Agudo Torrico (2012: 165-218). Asimismo, los trabajos -ya clásicos- de Turner (1980; 1988) sobre ritualismo, liminaridad y communitas, contienen planteamientos teóricos y conceptuales fundamentales para el abordaje de estos fenómenos desde la antropología simbólica de procedencia británica.

${ }^{2}$ La Semana Santa es una tradición inventada en el sentido teórico que le confirió al término el historiador británico Eric Hobsbawn (2002: 7-8): "El término "tradición inventada" se usa en un sentido amplio, pero no impreciso. Incluye tanto las "tradiciones" realmente inventadas, construidas y formalmente instituidas, como aquellas que emergen de un modo difícil de investigar durante un período breve y mensurable, quizás durante unos pocos años, y se establecen con gran rapidez. [...] La "tradición inventada" implica un grupo de prácticas, normalmente gobernadas por reglas aceptadas abierta o tácitamente y de naturaleza simbólica o ritual, que buscan inculcar determinados valores o normas de
} 
e ideológicos de la sociedad que las celebra. Porque la fiesta es algo que va más allá de la expresión pública de las características, identificaciones y (supuestas) tradiciones de una comunidad. Cumple la función de ser también "un vehículo privilegiado que el poder tiene en su mano para transmitir una determinada imagen de sí mismo al pueblo sobre el que ejerce ese mandato. [...] la imagen que da a través de la fiesta ese Estado, capaz, por otra parte, de inventar la tradición para usarla en su beneficio, no es la representación de lo que es, sino de lo que desea que el pueblo sobre el que ejerce ese mandato crea que es" (Cordero Olivero (1997: 138).

Las fiestas y rituales poseen un código de significados sociales y cumplen, por tanto, una serie de funciones latentes que difieren de las que son publicitadas como explícitas ${ }^{3}$. Para los trabajos antropológicos, esas funciones sociales y políticas no explícitas, latentes, son lo verdaderamente interesante de cara a realizar un análisis histórico. Las mismas varían según las transformaciones ideológicas y políticas que se dan en las sociedades donde tienen lugar las celebraciones. Este ámbito de estudio de las funciones latentes tiene como objetivos analizar y conocer los distintos grupos sociales que organizan el proceso festivo, examinar la relación de los diferentes grupos entre sí y con los poderes establecidos -civil, eclesiástico, militar...-, y definir el papel simbólico que juega la fiesta en el plano social, político e ideológico de la comunidad abordada ${ }^{4}$.

Este artículo pretende una aproximación a la Semana Santa de la ciudad de Huelva durante el primer franquismo, concretamente a las semanas santas del período histórico desarrollado entre 1937 y 1951. Un acercamiento a sus cofradías y sus prácticas ceremoniales públicas, pero también a sus significaciones y funciones políticas, a su conformación como espacios sociales y simbólicos en los que se reprodujeron los valores del Nuevo Estado, donde convivieron y se expresaron las representaciones ideológicas y simbólicas de los proyectos políticos de los heterogéneos grupos franquistas, sus diversos ima-

comportamiento por medio de su repetición, lo cual implica automáticamente continuidad con el pasado. De hecho, cuando es posible, normalmente intentan conectarse con un pasado histórico que les sea adecuado. [...] Sin embargo, en la medida en que existe referencia a un pasado histórico, la peculiaridad de las "tradiciones inventadas" es que su continuidad con éste es en gran parte ficticia".

${ }^{3}$ En el caso de las cofradías de Semana Santa sus funciones básicas y explícitas serían el culto público, la práctica de la caridad o la ayuda mutua y el apostolado o la formación católica y cofrade.

${ }^{4}$ Para una profundización en la significación social y política de las cofradías y la definición del marco de sus funciones latentes remitimos a: Rodríguez Becerra (1985), Rodríguez Mateos (1998: 127-244), Moreno Navarro (1999: 38-149), Hurtado Sánchez (2000), Moreno Navarro (2006b: 141-162) y Domene Verdú (2017). 
ginarios -los propios del fascismo falangista, del tradicionalismo reaccionario carlista y de los elementos monárquicos y católicos-, así como las liturgias fascistizadas, militarizadas y católicas que invadieron las procesiones cofradieras onubenses ${ }^{5}$.

\section{De la cuaresma republicana a la pasión y muerte de la cruzada nacional}

Una parte importante de la jerarquía de la Iglesia católica española, compuesta en su mayoría por "un clero envejecido, educado en el integrismo, poco culto y nada sensible a los problemas sociales" (Casanova Ruiz, 2005: 329), había percibido el advenimiento de la República como una verdadera catástrofe. Ciertamente, "un sector numeroso del episcopado estaba compuesto de integristas, quienes en muchos casos debían su nombramiento o promoción a la dictadura, consideraban la República como una desgracia y estaban poco dispuestos a la transigencia" (de la Cueva Merino, 1998: 216). No es menos cierto, también, que una parte -minoritaria, eso sí- de los jerarcas eclesiásticos había aceptado el statu quo asignado a la Iglesia en la nueva forma de Estado republicana y pusieron en práctica una actitud conciliadora con los nuevos poderes políticos ${ }^{6}$.

\footnotetext{
${ }^{5}$ Para la consecución de estos objetivos se han utilizado diferentes fuentes de producción de datos. El trabajo de campo realizado en el Archivo Municipal de Huelva (AMH), el Archivo Histórico Provincial de Huelva (AHPH), la Hemeroteca de la Diputación Provincial de Huelva (HDPH) y en diferentes archivos de carácter privado de varios informantes, ha sido clave para lograr este análisis histórico del ritual en el período abordado. Las diversas fuentes hemerográficas locales -el Diario de Huelva (AMH), La Provincia (AMH) y, sobre todo, el diario Odiel (HDPH)- han supuesto los regueros mediante los cuales se ha canalizado gran parte de la información. Asimismo, las publicaciones cofradieras de la época -tales como las revistas Mater Dolorosa, Lignum Crucis, Onuba Sacra, Calvario y otras- han contribuido de manera decisiva a satisfacer ciertos objetivos del trabajo. La inmensa mayoría de las publicaciones cofradieras de esos años han sido consultadas en el Fondo Diego Díaz Hierro (AMH), así como en los archivos privados de Elena García de Soto Camacho y Rafael Luis Alfaro Sánchez. No menos importantes han sido los datos y análisis aportados por la bibliografía preexistente acerca de la temática: la relativa a la historia de la Semana Santa de Huelva, principalmente los trabajos pioneros de Díaz Hierro (1951; y otros, legados en su fondo documental), de Sugrañes Gómez (1988; 1998), Fernández Jurado (1997a; 1997b) y Moreno Navarro (2006a); así como obras destacas en la literatura científica sobre Semana Santa y primer franquismo: Hurtado Sánchez (2000), Sánchez Herrero (2003: 279-307), Richards (2005), Sánchez Garrido (2005), Hernández Burgos (2011: 282-291), Langa Nuño (2014), Navarro de la Fuente (2014), Rina Simón (2015; 2016) o Vincent (2017), entre otros. Además, la abundante documentación fotográfica recogida ha servido para el análisis de los modelos estéticos y expresivos y para visualizar las relaciones ceremoniales entre diferentes instancias de poder.

${ }^{6}$ En esta línea de conciliación cabe destacar el papel que jugaron importantes eclesiásticos como el nuncio Tedeschini o los cardenales Vidal i Barraquer y Eustaquio Ilundáin.
} 
Para la Iglesia, la proclamación de la República laica significaba su separación forzosa de la Monarquía católica, institución de la que tantos privilegios había heredado y con la que poseía una ligazón realmente profunda, pues con ella había tejido en España su particular alianza Trono-Altar ${ }^{7}$. La llegada a los puestos políticos de representantes del movimiento obrero y los primeros pasos de una sociedad de masas, que reclamaba derechos sociales y formas de gobierno democráticas, supuso una tormenta política que gran parte de la jerarquía eclesiástica no pudo soportar. Muchos eclesiásticos pusieron en marcha discursos apocalípticos y de abierto enfrentamiento, que proliferaron no sólo en los púlpitos de los templos sino por multitud de medios de prensa que la institución controlaba y que servían al ideario católico ${ }^{8}$. En poblaciones como Huelva, la Iglesia también se manifestaba a través de asociaciones religiosas

Por su parte, las figuras más representativas de la corriente reaccionaria y antirrepublicana serían las de los prelados Isidro Gomá y Pedro Segura, que se convertirían en las contrafiguras de Tedeschini y Vidal.

${ }_{7}$ En palabras de de la Cueva Merino (1998: 212), "se podría decir que la recuperación que había experimentado la Iglesia durante la Restauración había sido macrocefálica: había engrosado sus efectivos clericales, había "reconquistado" parte de la burguesía y de la clase media, había mantenido su presencia entre los campesinos del norte, había quizá fortalecido su ascendiente sobre estos grupos sociales a través de un modelo de catolicismo que exigía una adhesión más sentida; pero había perdido, en su conjunto, las grandes masas rurales del sur de España y las masas proletarias de todo el país. Eran masas no sólo perdidas, sino abandonadas por la Iglesia, como denunciaban algunos eclesiásticos más lúcidos; masas a "cuyo apostolado sólo se dedicaban algunos santos", mientras que "para el apostolado de las mujeres y de los ricos sobraban sacerdotes"; masas en cuyas barriadas se carecía incluso de la presencia física de la parroquia y del sacerdote; masas que miraban a la Iglesia como aliada de los ricos y poderosos, pues muchos clérigos y destacados seglares no sólo habían dejado de actuar ante la miseria del pueblo, sino que se habían opuesto a los medios y medidas necesarios para acabar con las injusticias, mientras patronos poco escrupulosos presumían de piedad. De este modo, con una parte importante de la población desafecta u hostil y habiendo ligado en exceso sus destinos a los de la monarquía, la Iglesia española iba a encarar la proclamación de la República".

${ }^{8}$ La prensa de izquierda anticlerical, por su parte, avivaba el fuego contra la imagen de los eclesiásticos, demonizándolos y culpándolos de todos los males del país, de multitud de ataques a la República y acusándolos de no aceptar el nuevo statu quo de debida subordinación al Estado soberano. No es de extrañar que estos relatos ganaran en popularidad cuando desde el lado de los obispos parecían imponerse las tesis más integristas sobre las escasas posturas conciliadoras: "El cardenal Segura, una vez más, se autoerigió en intérprete del parecer de todos los prelados españoles y con el asentimiento tácito o expreso de la mayoría, mas con la oposición de Vidal, los reparos de Ilundáin y algún otro y el disgusto evidente del nuncio, redactó y dio a luz a mediados de agosto [de 1931] una pastoral "colectiva", a cuyo pie estampó las firmas de todos los obispos de España”. En ella recogía la doctrina antiliberal y pontificia, condenando la separación Iglesia-Estado, la subordinación jurídica de la primera al segundo y lo que denominó como las "libertades de perdición", más concretamente la libertad de cultos. No reconocía ni un solo mérito del anteproyecto constitucional y lo consideraba una consagración del "ateísmo de Estado" (De la Cueva Merino, 1998: 225). 
como las cofradías que, al igual que en el resto de Andalucía, poseían un marcado tinte popular pero que -mayoritariamente- se encontraban dirigidas por representantes de las tradicionales élites conservadoras locales, familias pertenecientes a la burguesía media y alta y elementos monárquicos, con quienes una gran parte de los representantes eclesiásticos compartía los mismos intereses ideológicos y políticos ${ }^{9}$. Y, por medio de las hermandades, libraron pulsos y presiones a las instituciones civiles locales republicanas.

Desde los primeros meses tras la instauración de la República en abril de 1931 y la composición de un gobierno municipal de socialistas y republicanos federales y radicales, la Semana Santa se convirtió en uno de los terrenos simbólicos en los que se libraron diferentes batallas de una guerra fría entre los sectores onubenses conservadores, católicos y monárquicos, frente a los progresistas, laicistas y republicanos de izquierda. Los primeros, creyendo amenazados sus privilegios socioeconómicos, viendo en sus puestos tradicionales de poder político a republicanos y socialistas, y a sabiendas de que no era el momento de exponer abiertamente sus rechazos y hostilidades a la nueva forma de Estado, "envolvieron sus quejas y maniobras, llenas de intencionalidad política, con disfraces varios" (Espinosa Maestre, 2005: 26). Uno de los temas centrales de ese enfrentamiento latente fue la nueva legislación promulgada, secularizadora y laica -aunque durante el primer bienio con marcado tinte anticlerical-, y los incendios y destrozos que -entre el 10 y el 15 de mayo de 1931- anticlericales radicales de izquierda habían realizado en otras ciudades contra iconos y edificios religiosos ${ }^{10}$. La cuestión religiosa se convirtió en un delicado y trascendental centro de debate y conflicto y en un ele-

${ }^{9}$ Muchos de los miembros más destacados de las juntas directivas de las cofradías habían militado en el Partido Conservador y la Unión Patriótica durante la Restauración y la dictadura de Primo de Rivera. Baste comprobar la coincidencia de los nombres de muchos directivos cofrades con algunas de las élites políticas de los períodos nombrados. Para ello, aconsejamos ver García Díaz (2004).

10 "La quema de conventos y otras expresiones de ira anticlerical o sacrofóbica no eran, por otro lado, nuevas y habrían de volver a repetirse a lo largo de todo el período republicano. El incendio de edificios religiosos era una manera simbólica y expeditiva de hacer efectiva la anhelada destrucción del poder clerical, que por medios políticos no llegaba, y de así avanzar, mediante el fuego purificador, hacia la regeneración de España. Bastó la provocación monárquica y el ambiente creado en torno a Segura y otros clérigos refractarios para que saltase la chispa y se produjese la acción de los exasperados revolucionarios" (De la Cueva Merino, 1998: 220). Para profundizar, desde una perspectiva antropológica, en el antirritualismo católico, las destrucciones iconoclastas y la función simbólica de la violencia anticlerical contemporánea española, remitimos a los trabajos sobre la cuestión de Delgado Ruiz (1989; 1992; 1997a; 1997b; 2001; 2005). Asimismo, el tema de la cuestión religiosa durante la Segunda República ha sido ampliamente estudiado por De la Cueva Merino (1998; 2014). 
mento ideológico dotado de una enorme carga simbólica, fundamental para entender el desarrollo de todo el período republicano y la guerra civil.

Uno de los más significativos enfrentamientos que tuvo lugar entre el ayuntamiento de Huelva y los sectores católicos y conservadores onubenses, fue la aprobación por parte del pleno de una moción de un concejal socialista que instaba a hacer desaparecer de las calles y fachadas los azulejos e imágenes religiosas, entablándose con posterioridad un enconado pleito en los tribunales de justicia ${ }^{11}$. "Ni que decir tiene que esta polémica acrecentó el distanciamiento entre los elementos católicos y las autoridades republicanas. A fines de febrero de 1932 las ocho cofradías existentes en Huelva anunciaron que no efectuarían su estación de penitencia durante la Semana Santa" (Álvarez Rey y Ruiz Sánchez, 1990: 629).

Fernández Jurado (1997a: 280) afirma que el arzobispado de Sevilla -sede eclesiástica a la que pertenecía la provincia civil de Huelva-indicó que se adhería a la postura que adoptaron las hermandades onubenses, aunque el cardenal Ilundáin dejó entrever que su posición personal estaba al margen de la decisión tomada por las corporaciones. Esta postura en bloque de las hermandades debe entenderse como la respuesta que dieron al conflicto señalado los hermanos mayores y componentes de las juntas de gobierno, muchos de ellos ligados a partidos católicos, conservadores y de aspiración monárquica ${ }^{12}$. Si el Estado y las administraciones locales no querían los crucifijos ni las imágenes religiosas en las escuelas y los espacios públicos, tampoco echarían de menos las castizas procesiones de Semana Santa en las calles. Se trató de una estrategia política multiespacial -que se dio también en otras ciudades andaluzas- con el propósito de desprestigiar y restar popularidad al régimen republicano ${ }^{13}$.

${ }^{11}$ La tensión por el control del espacio público entre los católicos y partidarios de la religión y el clericalismo y aquellos elementos más representados por el laicismo y/o el anticlericalismo, tenía un largo recorrido y fue realmente patente desde, al menos, la segunda mitad del siglo XIX. En La Parra López y Suárez Cortina (1998), encontramos una cuidada síntesis sobre el desarrollo de la tensión entre clericales y anticlericales desde finales del siglo XVIII.

${ }^{12}$ Hernández Burgos (2011: 283-284) afirma que, en el caso de Granada, "buena parte de la cúpula de las hermandades religiosas estaba formada por los sectores más acomodados de la sociedad [...], las Juntas de Gobierno de las Hermandades y el control de las mismas, permaneció en manos de elementos conservadores de la ciudad que, asiduamente, formaban parte de los partidos derechistas del momento". Moreno Navarro (2006a: 267) señala que "las cofradías onubenses decidieron suspender sus salidas en el contexto del creciente enfrentamiento entre las jerarquías de la Iglesia y los sectores católicos más alineados con esta -en los que se incluían los dirigentes de las hermandades, pertenecientes a familias claramente conservadoras- y el nuevo régimen republicano, con su Constitución laica".

${ }^{13}$ Un proceso de boicot similar se dio en la Semana Santa de Sevilla, como sostiene Moreno Navarro (2006b: 243-276). Hernández Burgos (2011: 285) señala que en Granada 
En palabras de Moreno Navarro (2006b: 243) -que, aunque dirigidas a la situación que se desarrolló en Sevilla, pueden ser perfectamente extrapoladas al caso onubense-, "la Semana Santa fue utilizada por la mayoría de los dirigentes de las cofradías como un arma de presión política contra la legalidad republicana y descaradamente a favor de la derecha no sólo ideológica sino también directamente política, que trataba de desprestigiar al nuevo régimen. Como puede comprobarse, de lo que se trató fue de un boicot a la fiesta popular de la Semana Santa [...] por parte de las hermandades, las cuales siguieron los dictados de una mayoría de hermanos mayores comprometidos personalmente con la opción política de Gil Robles, utilizando a las cofradías como ariete contra la Constitución aprobada democráticamente por la Cortes de la República". Esa fue la postura de fuerza adoptada por los hermanos mayores y directivos de las cofradías onubenses. Entendían que las procesiones eran un fenómeno exclusivamente religioso, despojado de elementos costumbristas y, en todo caso, ligado únicamente a la simbología y los valores monárquicos ${ }^{14}$. La decisión de las cofradías de suspender sus salidas procesionales se prorrogó durante un trienio y, en las semanas santas de 1932, 1933 y 1934, la ciudad estuvo desierta de procesiones.

Para 1935, con un gobierno radical-cedista a nivel estatal, de corte conservador y contrarrevolucionario, rectificador de las políticas laborales, sociales y eclesiásticas del primer bienio -como anhelaban la mayoría de directivos de las cofradías-, volvieron a reanudarse los desfiles procesionales ${ }^{15}$. Este

\footnotetext{
"la decisión de no procesionar en 1933 y, sobre todo, en 1934, fue fruto de las posiciones encontradas entre las diferentes cofradías y del argumento de que el régimen republicano no garantizaba la seguridad de los cortejos religiosos".

14 "para las derechas las procesiones eran un componente fundamentalmente de catolicidad connatural a España" (Hernández Burgos, 2011: 283). "Vinculaban a su monarquismo la conmemoración de la Semana Santa como en toda España se pretendía por entonces que la religión fuera patrimonio único y exclusivo de los monárquicos" (Chaves Nogales, 2013: 68). La Restauración había sido un período de fuerte auge para la Semana Santa de Huelva. Durante este período se habían fundado cuatro cofradías -San Francisco, Pasión, la Buena Muerte y la Oración en el Huerto- y reorganizado otras como la Vera Cruz, el Nazareno o el Santo Entierro. En realidad, -siguiendo a Hobsbawn (2002)- se había inventado la tradición de la Semana Santa contemporánea, con las formas expresivas y estéticas tal y como las conocemos, y la ligazón de las corporaciones al monarquismo fue aún más intensa.

15 "a lo largo del bienio rectificador se promulgaron otras normas favorables a los intereses de la Iglesia [...]. A través de estas y otras disposiciones, si bien no se abolía expresamente la legislación anticlerical del primer bienio, se anulaban los efectos más sobresalientes de la misma y se daba un respiro a la Iglesia. [Pero esta] "rectificación" auspiciada por radicales y cedistas no se limitó a dar marcha atrás en materia de legislación eclesiástica: concernía también a otros aspectos afectados por el tenor reformista del primer bienio. Así, por ejemplo, la legislación laboral y social aprobada durante los dos años anteriores fue sistemáticamente incumplida en 1934 y 1935 y la reforma agraria sufrió un serio retroceso" (de la Cueva Merino, 1998: 248).
} 
hecho, unido al interés del ayuntamiento por recuperar unas fiestas llenas de tipismo y al cambio de actitud en los principales comerciantes locales -que decidieron apoyar económicamente a la Semana Santa por medio de una suscripción pública-, fue el caldo de cultivo en el que se originó esta nueva decisión por parte de las juntas de gobierno de las cofradías. El equipo de gobierno municipal colaboró directamente con las hermandades aportando la cantidad de tres mil pesetas, que debían ir destinadas "al pago de jornales de los obreros, a quienes se ocupa con motivo de las procesiones de Semana Santa" (Sugrañes Gómez, 1988: 13). De los tres años perdidos se quejaba amargamente el cofrade -y también concejal independiente conservador- Pedro Garrido Perelló, acusando del conflicto a los políticos locales laicistas y anticlericales de izquierda y celebrando el incentivo económico para que las cofradías volvieran a estar en las calles:

"Algunos exaltados que no ven más allá de sus narices, creían que eso de las procesiones eran para que ganasen los curas y celebraban sarcásticamente que éstas no saliesen a la calle, alegrándose de chinchar a los carcas, sin pensar que los que llevan los pasos son obreros, que los que elaboran la cera son obreros, que los que trabajan en los ramos de flores son obreros, que los músicos son obreros y que las túnicas de nazarenos y mantos los hacen los obreros y que para la preparación de esas maravillosas andas, cuajadas de luces y flores, son obreros los que trabajan.

La Semana Santa de Huelva, necesita para hacer estación unas diez mil pesetas sin contar el importe de túnicas que siempre hay que hacer y arreglo del deterioro de los pasos que anualmente es indispensable llevar a cabo, y esas pesetas, sirven para llevar a los hogares modestos, lo necesario para atender compromisos contraídos y en otros para comer porque hay muchos obreros que esperan los días de Semana Santa para ganar unos duros"16.

En esta rectificada situación, surgida -como acabamos de exponer- de la relación establecida entre las cofradías, el ayuntamiento, los comerciantes locales y al amparo del nuevo clima político estatal -que los dirigentes cofrades consideraban más favorable a sus intereses ideológicos y políticos-, comenzó a gestionar la organización de la Semana Santa una primigenia Agrupación de Cofradías que definió una especie de primera Carrera Oficial ${ }^{17}$. El presidente

${ }^{16}$ Fragmento de un artículo titulado 'Una equivocación espantosa', publicado en la revista Mater Dolorosa de 1935, p. 18, y firmado por Pedro Garrido Perelló. Este señor era un reconocido cofrade de la hermandad de los Judíos que había militado durante la Restauración en el Partido Conservador y que, tanto durante la dictadura de Primo como en tiempo republicano, sería concejal del ayuntamiento de Huelva, primero como conservador y, a partir de las elecciones del 12 abril de 1931, como independiente.

${ }_{17}$ García Díaz (2004: 25) y Moreno Navarro (2006a: 267) afirman que la iniciativa de crear la Agrupación de Cofradías se debe a la figura del cofrade Roque Borrero de la Feria, corredor de comercio y destacado hermano de la cofradía del Nazareno. 
de este incipiente colectivo cofradiero, manifestaba que la fiesta de la Semana Santa de Huelva

"puede considerarse como la más popular, porque de ella disfruta tanto el creyente como el no creyente, hasta tal extremo que estas manifestaciones religiosas están más bien conceptuadas en todas partes más como del pueblo que de la Iglesia"18.

Sin embargo, a principios de 1936, tanto el clima político municipal como el estatal volverían a cambiar con el triunfo en las elecciones de la coalición izquierdista del Frente Popular. Las diferencias ideológicas se acrecentaron aún más, registrándose -ya desde el mes de febrero- revueltas y acciones de enfrentamiento abierto entre elementos conservadores católicos y elementos izquierdistas laicistas y/o anticlericales. Las cofradías, en medio de este clima de tensión, polarización y confrontación, decidieron volver a la postura adoptada durante las tres primeras semanas santas republicanas, optando por no realizar la salida procesional.

Desatado el golpe de Estado del 18 de julio de 1936, al día siguiente dos columnas de hombres partieron desde la provincia de Huelva hasta Sevilla con el objetivo de acabar con el levantamiento comandado por el general Gonzalo Queipo de Llano. Uno de los grupos -el procedente de la capital- estaba compuesto por guardias civiles y el otro, repleto de milicianos, mineros y campesinos, procedía de la Cuenca Minera. El comando de guardias civiles llegó antes a Sevilla y, pese a su cometido de defender la legalidad constitucional republicana, se alineó con el bando de Queipo, tendiendo una sangrienta emboscada al grupo proveniente del norte de la provincia onubense. Todo concluyó con la muerte de multitud de mineros y milicianos y el posterior fusilamiento de otros tantos que habían sido hechos prisioneros. Según Abades y Cabaco (2009: 62), "como probable represalia a tan sangriento suceso, muchas iglesias, conventos y colegios de Huelva fueron completamente destrozados, perdiéndose así un gran número de altares, retablos, cuadros, imágenes, ornamentos y objetos de culto".

El alzamiento de los militares africanistas contra el gobierno frentepopulista y el Estado republicano, desencadenó en Huelva un breve pero intenso proceso revolucionario que tuvo en la iconoclasia su mayor exponente ${ }^{19}$. Dicho

${ }^{18}$ Escrito de Francisco García Prieto, presidente de la Agrupación de Cofradías de Huelva, dirigido al ayuntamiento onubense con fecha de 20 de febrero de 1935. Archivo Municipal de Huelva. Secretaría Especial. Legajo de Festejos. Citado en Sugrañes Gómez (1988: 12).

${ }^{19}$ Para aproximarnos al tema de la Guerra Civil en Huelva es imprescindible atender a la obra de Espinosa Maestre (2005). 
proceso revolucionario provocó, entre los días 20 y 21 de julio, la quema y el saqueo de edificios religiosos y el destrozo de todo tipo de bienes, enseres, imágenes y patrimonio cultual, algo que afectó a la totalidad de las cofradías onubenses. Desaparecieron archivos parroquiales y multitud de documentación referente a las hermandades. Únicamente la cofradía de los Judíos salvó sus imágenes y la mayor parte de su patrimonio de los disturbios al estar canónicamente erigida en la iglesia de la Merced, templo que no sufrió daños debido a que colindaba con el entonces Hospital Provincial y por encontrarse cerrada al culto por mandato de la diputación, que era su propietaria (Fernández Jurado, $1997 b)^{20}$.

A esta acción de violencia simbólica, anticlerical y revolucionaria, a esta martirización de las cosas sagradas ${ }^{21}$, la subyacía un profundo enfrentamiento ideológico, político y, sobre todo, de clase ${ }^{22}$. En general, en la ciudad de Huelva

${ }^{20}$ Para un acercamiento a las destrucciones y la violencia iconoclasta desarrollada en los lugares sagrados onubenses, ver Ordóñez Márquez (1968: 50-62).

${ }^{21}$ Utilizando las palabras del obispo Antonio Montero Moreno, citado en Casanova Ruiz (2005: 193-194).

22 Para el antropólogo británico Gerald Brenan (1996), esa violencia iconoclasta y anticlerical sería expresión de la profunda religiosidad de un pueblo que sentía que había sido abandonado y engañado, un acto de protesta porque la Iglesia no era lo que debía ser y no estaba -como dictaba el evangelio- al lado de los pobres. Para otros científicos sociales como Ordóñez Márquez (1968), más cercanos a las tesis que generó el franquismo, esos actos iconoclastas respondían a un proceso de persecución religiosa al que se había dado rienda suelta durante los años republicanos. Para Casanova Ruiz (2014), quizá fuera una protesta contra la sumisión de la Iglesia al ejército sublevado, al capital y a las clases acomodadas, a quienes las tesis izquierdistas acusaban de romper con el orden democrático. Lo cierto es que, a día de hoy, aún resulta difícil elaborar una explicación formal y rigurosa acerca de las motivaciones y las maneras en que se desarrollaron esos actos de violencia iconoclasta y anticlerical. Frente a la visión dominante que, tradicionalmente, los ha catalogado como hechos espontáneos de efervescente ira popular, podemos encontrar descripciones y relatos que hablan de acciones ritualizadas, escrupulosamente organizadas y, en muchas ocasiones, contando con la oposición y el pesar de los vecinos. Casanova Ruiz (2005: 182 y 193) señala que la "mofa carnavalesca de la parafernalia eclesiástica fue una de las muchísimas manifestaciones de esa ofensiva anticlerical". Se parodiaban procesiones entre burlas y blasfemias y, para ello, se utilizaban las vestimentas litúrgicas de los curas e incluso de las propias imágenes sagradas. Se apilaban esas imágenes - previamente mutiladas o no- sobre "otros objetos de culto, junto a los documentos municipales y eclesiásticos, a los registros de propiedad, religión y orden inextricablemente unidos", y al atardecer -siguiendo la descripción del rito que realizó la antropóloga norteamericana Susan Harding sobre la población aragonesa de Ibieca- prendían fuego al montón. Atendiendo a las palabras reflejadas en el martirologio onubense realizado por Ordóñez Márquez (1968: 5), esos exaltados iconoclastas izquierdistas “-decían- [que] ellos no perseguían a las monjas, que son mujeres como las demás; sólo perseguían a los santos que son de palo y no existen". Destrozaron y quemaron la mayoría de las imágenes sagradas de la ciudad, así como multitud de lugares y objetos de culto. En las paredes de la saqueada iglesia del Sagrado 
se respetó la vida del clero y de las personas de derechas "pero no sus símbolos ni sus propiedades. [...] fueron muy afectados el patrimonio de la Iglesia, las sedes de partidos políticos como Acción Popular y Falange y los centros de reunión tradicionales de la derecha económica", así como los domicilios de muchos grandes propietarios y componentes de la alta burguesía local (Espinosa Maestre, 2005: 144) ${ }^{23}$. La Iglesia católica y sus asociaciones -entre ellas las cofradías- fueron percibidas por los sectores más radicales y extremistas de la izquierda onubense como patrimonio simbólico exclusivo de aquellos que supuestamente actuaban en connivencia con los planes de los militares rebeldes, los grandes terratenientes y propietarios, los falangistas y los sectores católicos conservadores y tradicionalistas ${ }^{24}$. Y los más exaltados actuaron violentamente contra esos símbolos en respuesta al golpe de Estado y a los sucesos de Sevilla.

Acusaban a la Iglesia de ser cómplice del fracaso democrático en base a una oratoria que había precedido la insurrección y que, en lugar de llamar a la paz y al entendimiento, sirvió como fuente de sentido para abrir un "plebiscito armado", una "cruzada contra los sin Dios y los hijos de Caín", una contienda contra "los enemigos de Dios y de España", una guerra entre "las dos ciudades", una "operación quirúrgica en el cuerpo social de España"25. Una Iglesia

Corazón de Jesús se podían leer diferentes consignas: "Mueran los curas", "Viva el comunismo" o "Viva la República", entre otros. La hoz y el martillo presidían -pintados- la capilla bautismal y, en lo alto del coro, un letrero rezaba: "Local adquirido por la C.N.T." (Ordóñez Márquez, 1968: 54).

${ }^{23} \mathrm{Si}$ creemos los datos aportados tanto por Ordóñez Márquez (1968) como por Espinosa Maestre (2005), en la capital fueron asesinadas seis personas por la represión de la izquierda, entre las que había un único sacerdote, Mariano Caballero Rubio, de ideología carlista, coadjutor de la parroquia de San Pedro y capellán del grupo de requetés de Huelva. El 23 de julio, apenas dos días después del saqueo general de los templos capitalinos, le dispararon por la espalda cuando estaba siendo conducido hasta la prisión. Rápidamente, fue trasladado a la casa de socorro y, posteriormente, al hospital, donde falleció al día siguiente. Ciertamente, muchos otros curas estuvieron retenidos en las improvisadas cárceles locales y, quizá gracias a ello, sólo uno fuese asesinado. "En ninguno de los seis asesinatos cometidos en Huelva puede probarse la participación o inducción de las autoridades republicanas, incapaces sí de controlar abiertamente el caos provocado por la sublevación del 18 de julio" (Espinosa Maestre, 2005: 143).

${ }^{24}$ Resulta crucial hablar exclusivamente de católicos en lugar de cristianos, ya que-como bien afirma Raguer Suñer (2010: 51)- es "significativo, a este respecto, que los protestantes, que también son cristianos, no fueron perseguidos en la zona republicana, y sí lo fueron en la franquista".

${ }^{25}$ En palabras de Espinosa Maestre (2005: 530), "para la Iglesia todo era una provocación, desde un sindicato de clase hasta un periódico de izquierdas o una escuela laica. Por lo mismo todo lo que relegara a la Iglesia al ámbito de las creencias privadas restándole poder e influencia en la esfera pública y estatal era considerado como un gravísimo atenta- 
que tomó partido y posición de batalla en esa guerra -que entendía como cruzada-porque "Dios lo quiere"26. Ya lo había advertido el padre agustino Ángel Monjas a los cofrades de Huelva en las páginas de la revista Mater Dolorosa de 1935:

"En vano se pretende desalojar a Cristo de la tierra cerrándole las puertas de la escuela, del hogar, de las leyes, de las artes, de la ciencia y de la tumba. Con esto solo se ha conseguido formar generaciones de odio y de destrucción que

do. Desde este punto de vista lo que en este sentido pudiera ser aprobado por la República se convertía en un peligro para su existencia, que ellos gustaban asociar con la de España. De ahí que cuando se produce la sublevación fascista a la Iglesia no se le plantea duda alguna. Se une, como venía haciendo tradicionalmente, a quienes le pueden devolver su poder e influencia. Ello le acarreó a escala nacional varios miles de víctimas de religiosos y religiosas brutalmente asesinados por los sectores izquierdistas más radicales. Y puesto que la guerra enfrentó a clases sociales, pierden la vida en unión de derechistas, propietarios, falangistas o militares". Estos izquierdistas "no mataban a los sacerdotes y religiosos por odio a Cristo, sino por el papel político de la Iglesia" (Raguer Suñer, 2010: 51). No es casual que congregaciones de religiosas entregadas a la beneficencia y la caridad como "las Hermanitas de los Pobres salieran ilesas de la persecución" (Casanova Ruiz, 2005: 191).

${ }^{26}$ El primado de España, Isidro Gomá, el obispo de Salamanca, Enrique Pla y Deniel, y el eclesiástico Aniceto de Castro Albarrán, fueron los ideólogos clericales más destacados del pacto de sangre firmado por la Iglesia católica y el ejército del bando rebelde y, probablemente, los jerarcas católicos más entregados a la construcción simbólica de la legitimación y sacralización de la guerra civil. "Aquella contienda fratricida tuvo un fuerte componente religioso: de sacralización de un pronunciamiento fallido por un lado, de persecución religiosa por el otro" (Raguer Suñer, 2010: 48). "en una zona los curas querían confesar a toda costa a los rojos y obligarles a gritar "¡Viva Cristo Rey!" antes de morir, y en la otra quienes mataban a los curas les obligaban a blasfemar, a sumergirse en el último soplo de vida en la apostasía. Así de religiosa, por exceso o por defecto, resultó aquella contienda" (Casanova Ruiz, 2005: 196). "En la zona republicana, la Iglesia fue objeto -ahora sí- de una terrible persecución, difícilmente parangonable, en cuanto a número de víctimas, a cualquier otra de ningún tiempo. En la zona sublevada, que pronto se empezaría a autodenominar "nacional", lo que se inició como pronunciamiento militar se convertiría, sin mucha demora, en "Cruzada" religiosa respaldada por la Iglesia" (de la Cueva Merino, 1998: 260). "Destinada a cohesionar la retaguardia y a legitimar la violencia contra el enemigo bajo el manto de su recreación en positivo, (como una limpieza necesaria de la patria y de la comunidad nacional de los elementos enfermos), y por más que fuese sintética e integradora, ni la noción de la Cruzada sería unívoca, ni dejaría de suscitar tensiones internas dentro de los sublevados por la consagración del relato. Lo cual era reflejo evidente de la heterogeneidad de sus orígenes intelectuales tanto cuanto de los tiempos, no siempre inmediatos, en la asunción de un relato común. [...] el de la Cruzada fue un relato integrador de las diferentes sensibilidades y proyectos políticos de la retaguardia sublevada: en cierta medida, un coagulante identitario. [...] En la medida en que se catolizó el fascismo, durante la guerra también se fascistizó el catolicismo. Sus relatos convergieron en territorios compartidos y porosos, espacios de definición y redefinición conceptual. Y uno de los más poderosos fue precisamente el de la Cruzada" (Rodrigo, 2014: 556-557). Para estudiar en mayor profundidad la construcción simbólica de la guerra y la dictadura a través de los imaginarios religiosos, remitimos a los trabajos de di Febo (1988), Casanova Ruiz (2005), Box Varela (2008), Hernández Burgos (2011; 2016: 140-143), Rodrigo (2014) o Rina Simón (2015; 2016). 
llevan a la Sociedad a la bancarrota de todo lo más noble y sagrado. Pero, a pesar de todo repetimos, la verdad de las palabras de Jesús quedará flotando sobre el desquiciamiento social y al grito sacrílego del mundo equivocado, 'no queremos por Rey al Cristo', contestará la Iglesia, siempre inmortal, como lo es su Fundador divino, con este lema glorioso: Cristo vence, Cristo reina, Cristo impera" 27.

Tanto la jerarquía eclesiástica como los nacionales y militares rebeldes, fueron conscientes muy rápidamente de las ventajas de la entrada de lo sagrado en el conflicto ${ }^{28}$. Y así, se fue forjando todo un conjunto de mitos, metarrelatos, imaginarios y símbolos resignificados que servirían para bendecir y legitimar la guerra, para sacralizarla y, posteriormente también, para construir la memoria y las tesis de los que vencieron.

\section{La construcción simbólica del franquismo de posguerra}

Gracias, en gran medida, a la bendición otorgada por la Iglesia católica, la deificación y el culto consagrado a Franco -a través de las diferentes conceptualizaciones que se realizaron sobre el caudillaje ${ }^{29}-\mathrm{y}$ un nacionalcatolicismo contrarrevolucionario, tradicionalista y profundamente fascistizado, se convirtieron en los elementos ideológicos en los que confluyeron -con mayores y menores tensiones- los heterogéneos grupos políticos que conformaron el bando de la España nacional ${ }^{30}$. El Movimiento se ideó como una comunidad de elegidos que, por medio de Falange Española Tradicionalista y de las JONS -partido fascistizado en el que Franco procuró unificar a falangistas y a tra-

${ }^{27}$ Fragmento del artículo 'La Iglesia es inmortal', firmado por el agustino Ángel Monjas y publicado en la revista Mater Dolorosa de 1935, p. 32.

${ }^{28}$ Los elementos más exaltados e integristas de la jerarquía eclesiástica "sirvieron en bandeja a los militares golpistas, que al principio no invocaban motivaciones religiosas, el título de cruzada, que les resultaría utilísimo de cara a la opinión internacional" (Raguer Suñer, 2010: 48).

${ }^{29}$ Para el abordaje y la comprensión de las múltiples y diferentes concepciones y significaciones del caudillaje franquista, derivadas de los distintos modos de entender el concepto de caudillo por los grupos políticos que componían el régimen, remitimos a: Saz Campos (2012) y Moradiellos García (2016: 29-95).

30 "Un conjunto con una mentalidad cohesiva -la de los vencedores de la guerra- y un programa fundamental compartido: anticomunismo y antiizquierdismo en general, antidemocratismo y antiliberalismo, antinacionalismos periféricos, catolicismo y antimasonería, entre otros. Pero también incluía diversos proyectos políticos diferenciados: monarquía neoabsolutista carlista, monarquía autoritaria alfonsino-juanista, fascismo, corporativismo católico, tecnocracia ultracatólica, etc., que concurrían a la hora de pretender ganar cuotas de poder, o el poder total" (Thòmas Andreu, 2016: 17). Para atender a las diferencias simbólicas e ideológicas y las luchas por el poder entre las diversas familias que compusieron la dictadura franquista, ver: Saz Campos (2003), Box Varela (2008) y -el citadoThomàs Andreu (2016). 
dicionalistas carlistas ${ }^{31}$ - y sirviéndose, resignificando o, directamente, (re)inventando diversos ritos colectivos -como el caso de la Semana Santa-, instituyó una sincrética y mestiza liturgia que expresaba la comunión de los seguidores y de los diferentes grupos políticos con su caudillo. Un caudillo trascendental que ejercía un papel de sumo intérprete, por el que era exaltado -en palabras de di Febo (2016: 143) - como un "enviado de Dios" -Homo missus a Deo (Rina Simón, 2016: 177)_32.

Durante sus años fundacionales, el nuevo régimen se debatió entre dos modelos ideológicos para su cimentación: la construcción de un Estado corporativo, extremadamente nacionalista y de confesión católica, como pretendían los sectores católicos y monárquicos -tradicionalistas y alfonsinos- por un lado, o bien la edificación de un Estado totalitario fascista, que propugnaba el sector falangista del régimen. Entre ambos proyectos ideológicos hubo confluencias pero también tensos conflictos. Los franquistas más representados por las tesis fascistas falangistas pretendieron erigir un proyecto de "religión política" guiado por el liderazgo, carismático y providencial, ejercido por la figura de Franco ${ }^{33}$. Pero para que se diera una verdadera religión política habría

${ }^{31}$ Por medio del decreto de 19 de abril de 1937, el Generalísimo y Jefe del Estado se incautaba tanto del partido fascista Falange Española de las JONS como del monárquico carlista Comunión Tradicionalista, "los fusionaba y creaba un partido único -Falange Española Tradicionalista y de las JONS- y se otorgaba a sí mismo el poder máximo en tanto que nuevo "Jefe Nacional". El partido, aunque copiado en su ideología y estructura de FE de las JONS, era nuevo" (Thòmas Andreu, 2016: 19). Para aproximarse al estudio de la FET y de las JONS subyugada al caudillo, ver Thomàs Andreu (2001).

32 "Los ritos colectivos son actos fundamentales para la representación simbólica de los modelos políticos y religiosos al basar su incidencia en una numerosa participación, que refuerza la veracidad del discurso o acontecimiento que se está celebrando. Del mismo modo, facilita que el concepto de autoridad se presente como un modelo legítimo y justo por todos aceptado" (Rina Simón, 2015: 91). Di Febo (1988: 58) define la producción imaginaria católico-simbólica del mesianismo franquista de esta manera: "España es guiada por Franco, nuevo Moisés, a la cabeza del nuevo pueblo de Israel hacia el cumplimiento de la Gran Promesa; a su vez, el ejército 'cruzado', investido de la misión redentora de España está formado en defensa de la civilización cristiana contra la barbarie, empeñado en un choque entre el divino Jesús y el judío Carlos Marx". "el hilo conductor que une las etapas de la vida de Franco evoca el esquema hagiográfico propio de la vida de los santos: la premonición, los signos, la ejemplaridad y las virtudes" (di Febo, 2016: 143).

${ }^{33}$ Esta fue la pretensión del fascismo español, representado por el sector de los antiguos miembros de FE de las JONS. Gentile (2004: 57) afirma que se puede hablar de religión política "cuando una entidad política, por ejemplo la Nación, el Estado, la Raza, la Clase, el Partido, el Movimiento, se transforma en una entidad sagrada, es decir, trascendente, indiscutible, intangible y, como tal, se convierte en el eje de un sistema, más o menos elaborado, de creencias, mitos, valores, mandamientos, ritos y símbolos, transformándose así en objeto de fe, de reverencia, de culto, de fidelidad y entrega para los ciudadanos hasta el sacrificio de la vida, si fuera necesario. Cuando esto ocurre, nos encontramos ante la constitución de una forma moderna de religión política". 
sido indispensable la construcción de un modelo de nación sagrada y teleológica que se diferenciara de la religión católica, aunque heredara de ésta todo un conjunto de prácticas y fundamentos simbólicos, algo que en el régimen franquista nunca se dio por completo gracias a la omnipresencia de esa institución -clave en la legitimidad del alzamiento y del propio régimen-que fue la Iglesia católica. Más al contrario, lo que ocurrió fue la construcción de una identidad nacional mítica, fascistizada -sí-, pero consagrada al catolicismo, basada y fundamentada en su consustancialidad católica y, por tanto, indisolublemente unida a ella ${ }^{34}$.

La bendición concedida por la Iglesia a ese intento de sacralización de la política resulta fundamental para entender la deriva del ideario fascista de Falange y su posterior subordinación al ideario nacionalcatólico, pues la "coalición autoritaria" o "bloque político y social" franquista ${ }^{35}$ construyó su credo ideológico y su praxis política basándose en interpretaciones bíblicas, que fueron constantemente legitimadas por la jerarquía eclesiástica española. La España nacional era presentada como una especie de Iglesia-Pueblo, investida de la gracia de Dios, que caminaba hacia la redención, pagando por ella la sangre de sus mártires ${ }^{36}$ :

"Cristo derramó su sangre para salvar a la Humanidad. España, elegida de Cristo, derrama su sangre joven cumpliendo así, sencillamente, un glorioso destino marcado de salvar al Hombre descreído, materialista, sin más norte en su

${ }^{34}$ La Iglesia y sus adláteres nunca estuvieron subordinados en esa relación, de simbiosis y tensión al mismo tiempo, entre fascismo falangista y nacionalcatolicismo contrarrevolucionario, autoritario y tradicionalista. Más bien al contrario, "las autoridades católicas bendijeron a las instituciones sublevadas bajo un principio teocrático: sólo de Dios, y por tanto, de su Iglesia, emana el poder y la autoridad. El clero, lejos de tener un papel subordinado en la construcción de los imaginarios nacionales, capitalizó esferas simbólicas fundamentales en la construcción de las memorias de la dictadura. Nos encontraríamos ante un estado fascistizado protegido y legitimado por el manto legitimador de la Iglesia" (Rina Simón, 2016: 177).

${ }^{35}$ Utilizando las palabras con las que definió al bando nacional (Thomàs Andreu, 2016: 17). Esa coalición autoritaria estaba formada por diferentes grupos o sectores políticos: "el ejército, la Iglesia, el partido único creado en 1937, los carlistas de la Comunión Tradicionalista -no siempre integrados en el partido-, los alfonsinos -después juanistas- de Renovación Española, los ex cedistas, sectores patronales, empresariales, propietarios agrarios y aun decenas de miles de medianos y pequeños campesinos, sectores de las clases medias urbanas y rurales, etc., todos ellos católicos".

${ }^{36} \mathrm{El}$ culto a los muertos y los caídos -bien fueran por Dios y por España, caso del tradicionalismo político y católico, o por España (y por Dios), caso del fascismo falangista- fue una constante y un elemento simbólico fundamental durante los primeros años de la posguerra. Para profundizar en las complejas y diferentes teodiceas que se dieron en el seno del régimen y la celebración de sus prácticas rituales, ver: Box Varela (2008: 110-193). 
vivir que sus concupiscencias. Por la sangre, esto es, de España el Mundo se salva de nuevo de la invasión materialista. [...] De nuevo la Humanidad se redime por la sangre de los elegidos de Cristo, por la sangre española, que tiene en esta Semana de Pasión sabor y fecundidad, ejemplo vivo de cómo ha de ser el espíritu español auténticamente católico, profundamente cristiano"37.

Los metarrelatos, las tesis y los imaginarios de los nuevos poderes franquistas, hegemónicamente fundamentados en un reaccionario nacionalcatolicismo, contrarrevolucionario y tradicionalista, cargado de una retórica y prácticas fascistizadas, dictaban que España era un país unido de manera consustancial al catolicismo y que éste siempre había sido la fuente de sentido del ser español. Sin embargo, la introducción de corrientes ideológicas revolucionarias -como las marxistas y las anarquistas-, consideradas ajenas y contrarias al carácter consustancial cristiano, habían infectado los valores de una parte del país, la denominada España roja. Y ante ese ataque externo, esa invasión, tuvieron que responder las gentes de orden, las élites políticas conservadoras tradicionales, la Iglesia y el ejército sublevado. Y lo hicieron al modo ensayado durante todo el siglo XIX y comienzos del XX, con un pronunciamiento militar y el uso de la fuerza.

La ciudad de Huelva fue tomada por el ejército nacional el día 29 de julio de 1936, por lo que en suelo onubense la guerra duró unos escasos once días. A partir de ese momento comenzó una fortísima represión-desinfección ${ }^{38}$ y, en la esfera de lo simbólico y lo ideológico, un intenso programa de resocialización de la población en los valores nacionalcatólicos en proceso de fascistización y de los principios fascistas en proceso de catolización ${ }^{39}$.

Entre 1937 y 1941, FET y de las JONS fue la institución más vigorosa del régimen en la ciudad y, a través de su aparato y sus diversas organizaciones -juveniles Flechas Navales y Terrestres, Sección Femenina, Auxilio Social, etc.-, controló la propaganda, la prensa, parte de la educación -sobre todo la socialización política de la mujer y la juventud-y las fiestas locales -fueran éstas

${ }^{37}$ Breve párrafo correspondiente al artículo 'Gozo y dolor del Jueves Santo', publicado en el diario onubense La Provincia el Jueves Santo 25 de marzo de 1937, p. 3.

${ }^{38}$ Para aproximarnos a la represión de las fuerzas de la dictadura en Huelva, ver: Espinosa Maestre (2005: 335 y ss.) y Espinosa Maestre y García Márquez (2009). Asimismo, recientemente ha sido publicado un interesante estudio sobre la represión económica: Feria Vázquez (2016).

39 Saz Campos (2003: 159) señala que el fascismo falangista sale de la guerra catolizado mientras que las derechas tradicionalistas lo hacen profundamente fascistizadas. Box Varela (2008: 198) también revela este doble proceso de simbiosis ideológica que caracterizó el período fundacional de la dictadura franquista: "la catolización del discurso fascista falangista y la fascistización del discurso nacionalcatólico y contrarrevolucionario". 
religiosas o civiles- ${ }^{40}$. Sin embargo, una vez entrada la década de los cuarenta, la jerarquía eclesiástica local tomó partido en la dirección espiritual y el control simbólico de la religiosidad popular y las fiestas religiosas locales. Poco a poco, fueron desapareciendo de ellas los rasgos fascistizados; pero los políticos falangistas, los piquetes de escolta y sus bandas de música continuaron participando en todo tipo de actos y procesiones.

A partir de 1945, terminarían por imponerse definitivamente los principios nacionalcatólicos. El falangismo no se vio con posibilidades de sobrevivir en el nuevo contexto e incidió en su catolización -se recatolizó todavía más-, a la par que el propio régimen. De esta manera, de cara a la población, en las diferentes celebraciones desarrolladas en el espacio público, falangistas, tradicionalistas y católicos contrarrevolucionarios, continuaron mostrándose aún más en comunión.

Ciertamente, desde el final de la Guerra Civil hasta la conclusión de la Segunda Guerra Mundial, en España se dio una sinergia entre el fascismo falangista y el nacionalcatolicismo, aunque con una latente tensión entre ambos proyectos ideológicos, que pugnaban por ser hegemónicos el uno sobre el otro. Pero, con la caída de los regímenes de la Italia fascista y la Alemania nazi, la fascistización de la dictadura comenzaría a ser un problema para los intereses internacionales del régimen de Franco. El proyecto nacionalcatólico, representado por la Iglesia y sus adláteres políticos, comenzó entonces a adquirir preponderancia en las esferas de poder de la dictadura y, poco a poco, los militares y políticos más representados por las ideas fascistas falangistas irían desapareciendo de los gobiernos franquistas en favor de los católicos ${ }^{41}$. Y con esos

40 "Falange controló todas y cada una de las manifestaciones públicas de la ciudad de Huelva en su beneficio. No era de extrañar, pues, que propiciase determinadas celebraciones por su especial rentabilidad propagandística, dotase de nuevo sentido a otras y eliminase aquéllas que no siguiesen la ortodoxia ideológica del Movimiento [...]. La iglesia católica consiguió colocarse en una postura de fuerza al entronizarse como ideología del nuevo Estado, pero no cabe duda de que pagó un precio al ser monopolizada por el mismo como instrumento legitimador. Cualquier acto religioso estuvo organizado y, en cierta medida, controlado por el aparato de Falange, el más firme núcleo del nuevo Régimen en Huelva por encima del ejército que apenas tenía fuerza por tratarse de una ciudad de retaguardia y de los tradicionalistas que no pasaban de ser un grupo pequeño dentro del cual el elemento más activo eran sus milicias juveniles, 'Los Pelayos"' (Cordero Olivero, 1997: 140-141).

${ }^{41}$ A juicio de Carr (2009: 595), "el falangismo se había convertido en una molestia en el plano internacional" para los intereses de la dictadura y, por ello, Franco fue paulatinamente abandonando la tarea de fascistizar España e intensificando la imagen exterior de ser un país nacionalcatólico. 
ingredientes ideológicos -ahora ya hegemónicos- se iría edificando la reserva espiritual tridentina de Occidente ${ }^{42}$.

\section{Fascistización, militarización y recatolización (neo)tridentina en las populares procesiones de Semana Santa}

"Huelva ofrece hoy el espectáculo maravilloso de su Semana Santa. Nuestros enemigos, quisieron terminar con esta tradición, pero ha vuelto a resurgir con más empuje, con más brío y hoy, la noble pugna entre las distintas hermandades, le dan tanto brillo y esplendor que no tienen nada que envidiar nuestras procesiones, a las de otras capitales"43

En los disturbios que acaecieron en Huelva durante los días 20 y 21 de julio de 1936, pereció la práctica totalidad del patrimonio artístico religioso de la ciudad, siendo las cofradías de Semana Santa las corporaciones más afectadas por el proceso revolucionario emanado de la intentona golpista. La cofradía de los Judíos quedó fosilizada, siendo la única hermandad que conservó sus imágenes sagradas y manteniéndose como el único resquicio de la Semana Santa regionalista onubense. Entre 1937 y 1951 tendría lugar no sólo la reorganización de las cofradías existentes en la ciudad con anterioridad a la guerra sino un éxtasis fundacional que duplicaría la nómina de hermandades penitenciales.

Las cofradías del Nazareno, San Francisco, Pasión, la Buena Muerte y la Oración en el Huerto comenzarían a reorganizarse en 1937, año en que se fundó también la cofradía del Silencio. La desorganizada hermandad de la Vera Cruz se fusionaría con la de la Oración en el Huerto en una nueva archicofradía en 1938. En 1939 se ideó la fundación de la hermandad de la Victoria. En 1943 se constituiría la cofradía de los caballeros Excombatientes y Mutilados. Entre 1943 y 1944 sería reorganizada la última hermandad de las exis-

\footnotetext{
42 "Varias veces he proclamado que en las líneas maestras de nuestra política no sólo nos interesan los bienes materiales, sino el orden moral que los presida; el pretender apartar la política de la Ley de Dios, como en muchos países se ha querido, es dejar penetrar en ella todos los materialismos e inmoralidades, ya que no hay regla moral que pueda sustituirla. La mayor parte de los males de la sociedad se deben al laicismo; y precisamente por haber colocado en nuestro Movimiento político lo espiritual por encima de lo meramente material, son muchos los que han llegado a considerarnos como la reserva espiritual del Occidente". Discurso de Franco, a través de los micrófonos de Radio Nacional de España y TVE. Madrid, 30 de diciembre de 1962.

${ }^{43}$ Fragmento de un artículo, firmado bajo el pseudónimo de Valero, publicado en la primera revista de la Comisión de Cofradías onubenses -denominada Calvario- de 1945. Consultada en el Fondo Díaz Hierro del Archivo Municipal de Huelva. Hemeroteca 79, S. 45.
} 
tentes con anterioridad a la guerra, la del Santo Entierro. En 1944 vería la luz la cofradía de las Tres Caídas. En 1947 sería fundada la Borriquita y, en 1949, las cofradías de los Estudiantes y la Sagrada Cena. Por último, en 1951 se crearía la del Descendimiento.

\begin{tabular}{|c|c|c|c|c|}
\hline Cofradía & $\begin{array}{l}\text { Año de } \\
\text { fundación }\end{array}$ & $\begin{array}{c}\text { Año de } \\
\text { reorganización }\end{array}$ & $\begin{array}{c}\text { Sede canónica } \\
\text { (entre 1937-1951) }\end{array}$ & $\begin{array}{l}\text { Referente } \\
\text { devocional }\end{array}$ \\
\hline El Santo Entierro & $\begin{array}{l}\text { Anterior } \\
\text { a } 1572\end{array}$ & $\begin{array}{c}\text { Entre } 1943 \\
\text { y } 1944\end{array}$ & P. de San Pedro & $\begin{array}{l}\text { Virgen de la } \\
\text { Soledad }\end{array}$ \\
\hline La Vera Cruz & $\begin{array}{c}\text { Anterior a } \\
1583\end{array}$ & $\begin{array}{l}1938 \text { (una vez } \\
\text { fusionada con } \\
\text { la Oración) }\end{array}$ & P. de la Concepción & $\begin{array}{c}\text { Virgen de los } \\
\text { Dolores }\end{array}$ \\
\hline El Nazareno & $1583 / 1591$ & 1937 & P. de la Concepción & $\begin{array}{l}\text { N. P. Jesús } \\
\text { Nazareno }\end{array}$ \\
\hline Los Judíos & $1772 / 1792$ & $\begin{array}{l}\text { (Apenas sufrió } \\
\text { destrucciones) }\end{array}$ & I. de la Merced & $\begin{array}{c}\text { María } \\
\text { Santísima de } \\
\text { los Dolores }\end{array}$ \\
\hline San Francisco & 1893 & 1937 & C. de San Francisco & $\begin{array}{l}\text { Virgen de la } \\
\text { Esperanza }\end{array}$ \\
\hline Pasión & 1918 & 1937 & P. de San Pedro & $\begin{array}{c}\text { N. P. Jesús } \\
\text { de la Pasión }\end{array}$ \\
\hline La Buena Muerte & 1921 & 1937 & $\begin{array}{l}\text { P. de San Pedro } \\
\text { (hasta 1940) / P. de } \\
\text { la Concepción }\end{array}$ & $\begin{array}{l}\text { Virgen de la } \\
\text { Consolación }\end{array}$ \\
\hline $\begin{array}{l}\text { La Oración en } \\
\text { el Huerto }\end{array}$ & 1922 & $\begin{array}{c}1937 \text { (fusionada } \\
\text { en } 1938 \text { con la } \\
\text { Vera Cruz) }\end{array}$ & $\begin{array}{c}\text { I. de la Merced } \\
\text { (hasta 1939) / } \\
\text { P. de la Concepción }\end{array}$ & $\begin{array}{c}\text { Cristo de la } \\
\text { Oración en el } \\
\text { Huerto }\end{array}$ \\
\hline El Silencio & $\begin{array}{c}1937 \\
\text { (segregada del } \\
\text { Nazareno } \\
\text { en 1944) }\end{array}$ & & P. de la Concepción & $\begin{array}{c}\text { Virgen de la } \\
\text { (Amargura } \\
\text { en su) } \\
\text { Soledad }\end{array}$ \\
\hline La Victoria & 1940/1941 & & $\begin{array}{l}\text { P. del Corazón } \\
\text { de Jesús }\end{array}$ & $\begin{array}{c}\text { Virgen de la } \\
\text { Victoria }\end{array}$ \\
\hline Los Mutilados & 1943 & & C. de San Francisco & $\begin{array}{l}\text { Virgen de la } \\
\text { Paz y Cristo } \\
\text { de la Victoria }\end{array}$ \\
\hline
\end{tabular}




\begin{tabular}{l|c|c|c|c}
\hline Cofradía & $\begin{array}{c}\text { Año de } \\
\text { fundación }\end{array}$ & $\begin{array}{c}\text { Año de } \\
\text { reorganización }\end{array}$ & $\begin{array}{c}\text { Sede canónica } \\
\text { (entre 1937-1951) }\end{array}$ & $\begin{array}{c}\text { Referente } \\
\text { devocional }\end{array}$ \\
\hline Las Tres Caídas & 1944 & $\begin{array}{c}\text { I. de la } \\
\text { Milagrosa (hasta } \\
\text { 1947) / P. del } \\
\text { Corazón de Jesús }\end{array}$ & $\begin{array}{c}\text { N. P. Jesús } \\
\text { de las Penas }\end{array}$ \\
\hline La Borriquita & 1947 & & P. de San Pedro & $\begin{array}{c}\text { Cristo de la } \\
\text { Entrada en } \\
\text { Jerusalén }\end{array}$ \\
\hline Los Estudiantes & 1949 & & P. del Corazón de & $\begin{array}{c}\text { Cristo de la } \\
\text { Sangre }\end{array}$ \\
\hline La Sagrada Cena & 1949 & & P. del Corazón \\
de Jesús & $\begin{array}{c}\text { Cristo del } \\
\text { Amor }\end{array}$ \\
\hline $\begin{array}{l}\text { El } \\
\text { Descendimiento }\end{array}$ & 1951 & & P. de San Pedro & $\begin{array}{c}\text { Cristo del } \\
\text { Descendi- } \\
\text { miento }\end{array}$ \\
\hline
\end{tabular}

Al ensañamiento con los objetos sagrados y de culto que se produjo en el período revolucionario abierto en la ciudad tras el alzamiento, la Iglesia católica y las autoridades franquistas locales respondieron con un intenso programa de recristianización y de recuerdo a los caídos que, en las poblaciones de la retaguardia como Huelva, estuvo plagado de procesiones de desagravio y rogativas, ceremonias y ritos colectivos impregnados de un evidente trasfondo político. Entre 1937 y 1939, las procesiones de Semana Santa tuvieron carácter de excepción y estuvieron salpicadas de un profundo paralelismo simbólico entre la pasión y muerte de Cristo, la de España -y sus caídos- y la de la propia Semana Santa onubense, gravemente mutilada, ultrajada y humillada en los disturbios guerracivilísticos por los enemigos de Dios y de España. Los cortejos procesionales fueron fuertemente transformados, manipulados y robustecidos con la presencia masiva de militares, requetés, falangistas y clero. Además, se intentó hacer ver a la población la palingenésica imagen de una fiesta tradicional renovada, rejuvenecida y engrandecida, que resucitaba -a la par que España- gracias a la decisiva intervención de los nacionales (Cordero Olivero, 1997).

Bien es cierto que la participación de autoridades civiles y militares no fue algo novedoso en los desfiles procesionales de las semanas santas del régimen franquista, como sí lo fue la efervescencia de una estética fascistizada y paramilitar. La participación de militares y élites políticas tradicionales y conservadoras había sido una constante durante toda la Restauración. Lo realmente extra- 
ordinario fue su multiplicación, la invasión protagonizada en todas y cada una de las procesiones de Semana Santa y, sobre todo, los reconocimientos públicos y las relaciones simbólicas -a través de nombramientos honorarios, ofrendas y donaciones- que entablaron las cofradías y las diferentes autoridades ${ }^{44}$.

Pero los cortejos ceremoniales no sólo fueron aumentados con la participación de militares y autoridades políticas y religiosas sino también de nazarenos pertenecientes a otras cofradías. Para la Semana Santa de 1937, en los cortejos de cofradías como la Buena Muerte, San Francisco o los Judíos, pudieron participar hermanos y no hermanos de la corporación siempre que vistieran el hábito nazareno preceptivo. También participaron nazarenos de otras hermandades en virtud de permisos o deferencias, bien por no haber podido realizar la salida en su día, como acto de fraternidad y unión entre corporaciones o, simplemente, con la finalidad de engrandecer los cortejos penitenciales. De este modo, en la comitiva del paso de la Virgen de la Consolación procesionaron nazarenos de otras hermandades en acto de representación. La Virgen del Mayor Dolor de San Francisco también fue acompañada por nazarenos de otras cofradías. Con la Virgen de los Dolores de los Judíos desfilaron nazarenos de las hermandades de San Francisco y Pasión ${ }^{45}$. Esta circunstancia fue también repetida durante los años cuarenta en la primera salida de la hermandad de la Victoria -que fue acompañada por nazarenos de la Oración en el Huerto, probablemente por haber sido amadrinada por dicha corporación-, en las dos primeras de la Borriquita o tras la reorganización del Santo Entierro.

En 1937, la mayoría de las hermandades aún no habían podido reconstruir las imágenes perdidas el año anterior. La cofradía de Jesús de la Pasión pretendió procesionar con la cabeza de su antiguo y mutilado Cristo adosada al cuerpo de un maniquí, intento que fue rápidamente abortado por el arcipreste Julio Guzmán. La hermandad de San Francisco procesionó, sobre un paso de palio, una fotografía de su Virgen del Mayor Dolor ${ }^{46}$. La del Nazareno hizo lo propio con una pintura del Señor desaparecido, que fue revestida con una bandera rojigualda. La del Santo Entierro también procesionó el Viernes Santo de ese año, aunque nada se dice en la crónica del diario Odiel de las condiciones en las que lo hizo la imagen del Cristo, del que sólo se conservó la cabeza. El Jueves Santo también había salido la cofradía de los Judíos:

${ }^{44}$ En el caso de Granada, Hernández Burgos (2011: 286-287) también destaca que "la Semana Santa pasó por un proceso de "fascistización" y, sobre todo, militarización que marcó esta festividad durante un largo periodo de tiempo". "Era indispensable [...] militarizar y solemnizar las conmemoraciones y el recuerdo de los principales acontecimientos de la guerra" (Rina Simón, 2015: 96).

${ }^{45}$ Así se nos presenta en las crónicas del diario La Provincia de los días 23 (p. 2), 25 y 27 de marzo de 1937.

${ }^{46}$ Reseña del diario Odiel de 25 de marzo de 1937, p. 3. 
"el desfile de esta Hermandad resultó muy brillante, acaso el más vistoso de todos los celebrados en Huelva en esta Semana Santa" ${ }^{47}$.

Pero lo cierto es que, en esos años, cofradías como la del Nazareno parecían estar más centradas en contribuir a la construcción de la legitimidad de la causa nacional que en cumplir su función religiosa de culto público. El día 20 de marzo de 1938, la hermandad entregó la cantidad de ciento cincuenta pesetas al gobernador civil y militar tras la bendición de su nuevo titular cristífero en el atrio de la destruida iglesia de la Concepción. La finalidad del donativo era ser distribuido "en la forma que crea más conveniente" y como muestra de su adhesión a la causa franquista, siendo finalmente destinado "a la suscripción para las poblaciones liberadas"48. La ceremonia de bendición de la imagen tallada por el escultor Ramón Chaveli resultó intensamente simbólica, llena de plasticidad y con un marcado carácter palingenésico. El nuevo Nazareno, que venía a sustituir al Cristo destrozado en 1936 y a acaparar su fuerte devoción local, era bendecido -como el fruto de la semilla que germinaba, que resucitaba- en medio de las ruinas del mismo templo en que fue martirizado. La cofradía convocó a todo el pueblo católico de Huelva a asistir al acto de bendición y a la posterior procesión de traslado hasta la iglesia de la Milagrosa para aunar "sus plegarias pidiendo por nuestra muy amada Patria, por su Caudillo y por nuestro glorioso Ejército y Milicias"49.

Durante las semanas santas de 1937 y 1939, las cofradías fueron escoltadas, al comienzo de la procesión y en los diferentes pasos, por distintos cuerpos militares, policiales o paramilitares, a saber la guardia civil, requetés, la policía urbana y por piquetes de FET y de las JONS, algo que continuaría siendo habitual a lo largo del primer franquismo. Asimismo, todas las hermandades contaron con la participación en sus cortejos de multitud de autoridades civiles y militares, que presidieron los desfiles procesionales triunfalmente junto al clero. Las procesiones tenían carácter de rogativas, pidiendo a Dios y a la Virgen el fin de la contienda, la victoria franquista y la concesión de todo tipo de gracias espirituales al caudillo y al ejército del bando nacional.

"Empieza la Semana Santa, con su bagaje de fiestas a celebrar por la Iglesia Católica y para cumplimiento del pueblo español, cuya catolicidad lleva en sus fibras como algo consubstancial y, por tanto, insuperable, mal que pese al monstruo de la inversión que dijo que España había dejado de ser católica.

${ }^{47}$ Tanto la crónica de la procesión de los Judíos como la del Santo Entierro vienen recogidas en el Odiel de 27 de marzo de 1937, p. 4.

${ }^{48}$ Crónica del diario Odiel de 22 de marzo de 1938, p. 2.

${ }^{49}$ Así lo manifiesta un recorte de prensa hallado en la carpeta 178 del Fondo Díaz Hierro del Archivo Municipal, fechado el 19 de marzo de 1938. 


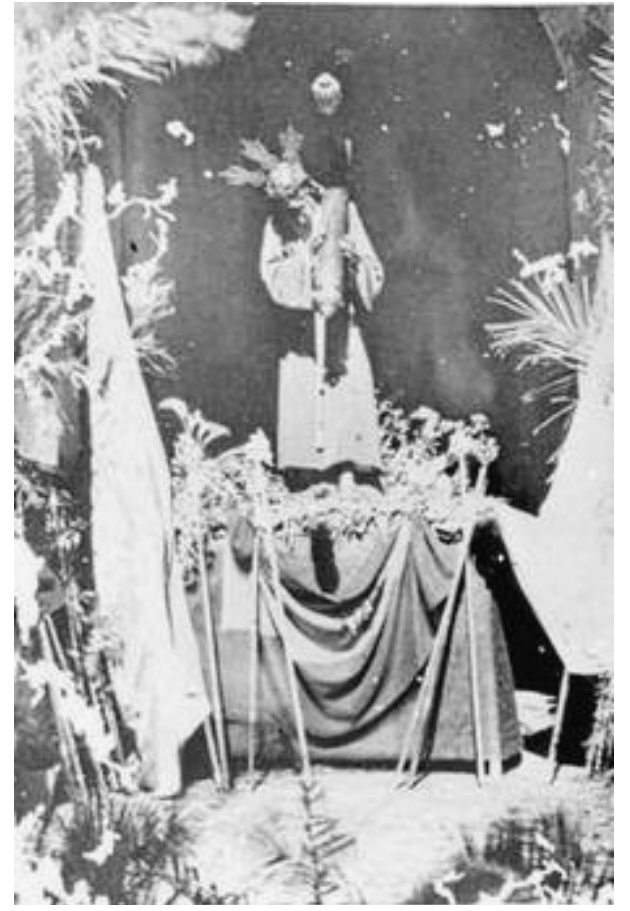

Imagen número uno ${ }^{50}$

Con el día de hoy ábrese, en la vida local, un paréntesis de recogimiento y de culto, que hemos de ser los primeros en guardar y rendir, uniendo nuestra voz a la del pueblo en las rogativas a Dios por la victoria final y definitiva de los ejércitos del Caudillo Franco, confiados a la protección del Señor de los Ejércitos"51.

Desde la Semana Santa de 1938, la procesión de la Soledad del Silencio, que cerraba los desfiles en la noche del Viernes Santo, jugó el papel de procesión de rogativas oficial:

"numerosos cofrades de esta hermandad y devotos de Nuestra Señora de la Amargura en su Soledad, y atendiendo a ruegos de nuestra dignísima Autoridad municipal, sacarán en procesión de penitencia y rogativa a la Santísima Virgen

${ }^{50}$ Instantánea de Nuestro Padre Jesús Nazareno en el acto de su bendición en el atrio de una ruinosa iglesia de la Concepción. El Cristo se halla colocado sobre una bandera de la España nacional que cubre unas modestas andas, utilizadas para su posterior procesión de traslado hasta la iglesia de la Milagrosa. 20 de marzo de 1938. Archivo del diario Huelva Información.

${ }^{51}$ Fragmento de un artículo titulado 'La Semana Santa', firmado por THUR en la sección 'Perfil onubense' del diario Odiel de 10 de abril de 1938, p. 5. 
con este título, a las diez de la noche, de la iglesia de la Milagrosa, el Viernes Santo, para pedir la pronta terminación de la guerra y que la Virgen derrame sus gracias espirituales sobre nuestro invicto Caudillo el Generalísimo Franco, y nuestro glorioso Ejército y Milicias, e invitamos a todas cuantas personas quieran asistir" 52 .

"procesión oficial de Nuestra Señora de la Amargura en su Soledad en memoria y sufragio de las almas de los que gloriosamente dieron su vida por Dios y por España en la pasada Cruzada" 53 .

Pero aunque la procesión del Silencio abanderara la oficialidad de los desfiles penitenciales entre las semanas santas de 1938 y 1944, año en que vuelve a desfilar la procesión catalogada como oficial por el arzobispado de Sevilla, la del Santo Entierro ${ }^{54}$, en realidad todos los desfiles fueron presididos por multitud de altos cargos públicos, militares y eclesiásticos, que solemnizaron e invadieron los cortejos ceremoniales de las cofradías existentes, marcados "por el dramatismo y el sentimiento patriótico" (Hernández Burgos, 2011: 290). Cada día de la Semana Santa, tanto el gobernador militar como el gobernador civil, ostentaban la presidencia de alguna cofradía. Junto a ellos se presentaba un alto mando local de FET y de las JONS y el arcipreste y/o el párroco de la iglesia donde se encontraba instituida la hermandad. Las jornadas en las que había más de una cofradía en las calles, ambos gobernadores solían delegar su representación en algún otro cargo político o militar para que presidiera en su nombre la procesión a la que les era imposible la asistencia.

Como hemos comentado, el clero también copó las vistosas presidencias de las procesiones junto a los distintos jerarcas del Movimiento. Bajo la intercesión del arzobispo Pedro Segura, del arcipreste Julio Guzmán y de los distintos curas de las parroquias donde había cofradías, las procesiones se pusieron al servicio de intereses y causas políticas, haciendo desaparecer la desdibujada frontera existente entre lo religioso y lo político. El 15 de marzo de 1938, el cardenal Segura publicaba una carta pastoral en la que manifestaba que las hermandades estaban "inseparablemente unidas a la vida no sólo religiosa, sino hasta cívica y militar" 55 . Lo que ponían de manifiesto los desfiles proce-

\footnotetext{
${ }^{52}$ Así lo narra la reseña que hace el diario Odiel el 10 de abril de 1938, p. 4.

${ }^{53}$ Reseña de la crónica del Diario de Huelva el día 10 de abril de 1941, p. 5.

${ }^{54}$ Según la página 3 de las actuales Reglas de la hermandad del Santo Entierro, esta cofradía "es desde tiempos inmemoriales la hermandad oficial de los desfiles procesionales de la Semana Santa de la ciudad de Huelva. Así lo reconoce el arzobispado de Sevilla en 1915, y así fue ratificada el 2 de octubre de 1989 por la Unión de Cofradías de la Semana Santa de Huelva, hoy Consejo de Hermandades y Cofradías de la Semana Santa de la ciudad de Huelva".

55 'Las cofradías y la vida cristiana' (BOEAS, 15 de marzo de 1938). Carta pastoral recogida en Hurtado Sánchez (2000: 169).
} 
sionales de esos años era la comunión pública existente entre FET y de las JONS, el Ejército rebelde y la Iglesia católica, cuerpo y alma del Nuevo Estado naciente. Y como ejemplo, la extraordinaria procesión triunfal que, a modo de rito de acción de gracias, protagonizaron la patrona de la ciudad y el Señor de Huelva, envueltos en el fervor y el arrobo de falangistas, requetés, monárquicos, militares, curas, cofrades y ciudadanos simpatizantes de la causa nacional.

La mañana del martes 28 de marzo de 1939 comenzó con un repique de campanas que, junto a las emisoras de radio, anunciaba que Madrid había sido tomada por las tropas franquistas. Era un martes de la Semana de Pasión y faltaban cinco días para que diera comienzo una nueva Semana Santa. Se convocó una jubilosa manifestación por la ciudad que fue presidida por los diferentes cargos públicos del Movimiento. La misma comenzó, en torno a las siete de la tarde, en el consistorio de la calle del Puerto y concluyó en la plaza de José Antonio Primo de Rivera, donde el alcalde, el director del diario Odiel, el jefe provincial de FET y de las JONS y el gobernador civil interino, pronunciaron fascistizados y patrióticos discursos. A esa misma hora era trasladada la Virgen de la Cinta desde el santuario del Conquero hasta el centro de la ciudad. La sección juvenil de FET y de las JONS, con su banda de cornetas y tambores, se unió al desfile procesional cuando la Cinta alcanzó la plaza de la Merced. Sobre las diez de la noche, la Virgen llegaba a la parroquia de la Purísima Concepción. Allí se adhirió a la procesión la imagen del Nazareno mientras el párroco, José Manuel Romero Bernal, pronunciaba un patriótico y apasionado discurso. La Cinta y el Nazareno recorrieron las principales arterias de la ciudad para recogerse a altas horas de la madrugada, bendiciendo la fundación de la hermandad de la España de Franco ${ }^{56}$. De nuevo lo divino legitimaba la causa franquista. Una divinidad que el Movimiento definía como protectora y garante del triunfo en la guerra y a la que se encomendaba para alcanzar la inmensa tarea de ganar la paz. Una práctica ritual que actuaba como ejemplo manifiesto de politización de lo sagrado y sacralización de la política.

Durante los años de 1937 y 1943 los iconos religiosos populares que sufrieron una mayor politización fueron el Nazareno y la Virgen de la Soledad del Silencio, además de la patrona de la ciudad, la Virgen de la Cinta. En el caso del Nazareno y la Cinta la razón era evidente; eran las devociones más importantes de Huelva y las autoridades locales del nuevo régimen se sirvieron de ellas para popularizar su causa y, en realidad, legitimarla. Por su parte, la procesión de la Soledad -que en esos años dependía y era organizada por la hermandad

56 'La conquista de Madrid en Huelva. Gran manifestación de júbilo. Vibrantes discursos patrióticos'. Crónica publicada por el diario Odiel de 29 de marzo de 1939, p. 2. 
del Nazareno- tuvo como finalidad hacerse cargo de la oficialidad que, hasta su desorganización, abanderaba la cofradía del Santo Entierro. Por tanto, dominar la cofradía del Nazareno durante los años fundacionales del régimen, supuso controlar el más importante icono y espacio simbólico de la Semana Santa. Un espacio en el que poder sacralizar las razones de la guerra, conmemorar a los muertos, rogar por la victoria de los nacionales $-\mathrm{y}$, posteriormente, celebrarla-, legitimar los valores del Nuevo Estado y ritualizar el culto a Franco ${ }^{57}$. Sin embargo, el régimen pronto creó y reprodujo nuevos iconos y más espacios ceremoniales en la Semana Santa que sirvieran para recatolizar, para mostrar la adhesión al ideario franquista, para conmemorar la guerra y a los caídos en ella -haciendo una similitud entre la pasión y el calvario de Cristo y la de Españay para celebrar la 'Victoria' y la 'Paz's8.

"Este año, por la paz que nos trajeron las armas victoriosas, la Semana Santa, como decimos, se ha celebrado con el máximo entusiasmo y renovado fervor. Quizá falten muchas imágenes veneradas que la horda destruyó en su loca vesania, pero la devoción erigió nuevos pasos y está aumentada por el recuerdo vivísimo de aquellos tres años que España sufrió su Pasión"

A la altura de 1940, Huelva poseía una población cercana a los cincuenta y siete mil habitantes. En 1950, se establecería en torno a los sesenta y cuatro

${ }^{57}$ Este hecho de controlar las devociones populares más arraigadas y construir un plástico marco de espectacularidad, ritualidad y fuerte simbolismo en torno a ellas, fue algo muy característico de las autoridades del naciente régimen franquista también en otras localidades. En Sevilla, lo hicieron con la Virgen de los Reyes, el Gran Poder y la Macarena, como bien han estudiado Langa Nuño (2014) y Navarro de la Fuente (2014). En Granada, con la Inmaculada Concepción y la Virgen de las Angustias (Hernández Burgos, 2011). En Málaga, con la Virgen de los Servitas y el Cristo de la Buena Muerte -que quedó ligado, de manera perenne, a la Legión- (Richards, 2005). En Cáceres, con la Virgen de la Montaña (Rina Simón, 2015). En el caso de Valladolid, Vincent (2017: 99) señala que la participación de FET en la Semana Santa se circunscribió a estar presente en las representaciones civiles de las procesiones y a aportar bandas de música. En palabras suyas: "el partido queda prácticamente invisible, sin papel alguno en la organización de la Semana Santa vallisoletana ni antes ni después del cambio de rumbo de la Segunda Guerra Mundial a favor de los aliados en 1943". La popularidad de la Semana Santa -en conjunto- emergió posteriormente, en la década de los cuarenta, cuando se inventó la tradición, unida al proyecto de recatolizar la ciudad y proporcionando "una oportunidad para afirmar una visión alternativa a la fascista".

58 "Esos Cristos que procesionaban en Semana Santa ensangrentados y muertos representaban a la nación martirizada que, tras la pasión del liberalismo, el marxismo, la masonería o el anticlericalismo, resucitaba por la acción del Movimiento y el Caudillo. Y la Virgen, cabizbaja y llorosa, era esa misma España, la madre de la patria y de los combatientes que dieron su vida por el ideal de la palingenesia y de la apocatástasis" (Rina Simón, 2016: 178).

${ }^{59}$ Fragmento del artículo 'Huelva rindió a sus veneradas imágenes todo el fervor de su catolicidad', publicado en el Odiel del Domingo de Resurrección 24 de marzo de 1940, p. 3, y firmado por Antonio Rebollo. 
mil ${ }^{60}$. El crecimiento demográfico, derivado de la industrialización y el éxodo rural, no se había disparado todavía. Sin embargo, entre 1940 y 1951 se vivió un crecimiento exponencial en número de cofradías, doblándose prácticamente las existentes. Con anterioridad al conflicto armado, Huelva contaba con ocho cofradías penitenciales. Como vimos, en 1938 las hermandades de la Vera Cruz y la Oración en el Huerto acordaron fusionarse en una nueva archicofradía, lo cual rebajó la nómina a siete. Sin embargo, durante la década de los cuarenta se produjo la fundación de ocho nuevas corporaciones penitenciales, elevándose a quince la nómina de hermandades para $1951^{61}$.

¿A qué se debió este espectacular fenómeno de efervescencia cofradiera? Los planteamientos más cercanos al régimen, los que hacían la prensa, las revistas cofrades y los historiadores franquistas locales, establecían los razonamientos y argumentos principales en un gran auge del sentimiento católico entre la población ${ }^{62}$. Una cualidad que identificaba a los ciudadanos onubenses como buenos españoles en un tiempo en el que el ser católico se confundía con el ser español ${ }^{63}$. Eran tiempos donde aún se dejaba notar fuertemente el espíritu de la Cruzada y la idea de convertir España en la reserva espiritual (neo)tridentina de Occidente. "Tiempos de retórica y apoteosis católica, de "totalitarismo divino"' (Casanova Ruiz, 2005: 19-20).

Sin embargo, frente a la tesis generada por los círculos de poder del régimen, podemos encontrar la evidencia de que este delirio fundacional respondiera a un fenómeno menos esencialista y más complejo, que fue la política

${ }^{60}$ Datos demográficos sobre 'Alteraciones de los municipios en los Censos de Población desde 1842' extraídos del INE: www.ine.es

${ }^{61}$ Las hermandades fundadas entre 1940 y 1951 fueron: la Victoria (1940/1941), los Mutilados (1943), el Silencio -que se segregó en 1944 de la del Nazareno-, las Tres Caídas (1944), la Borriquita (1947), los Estudiantes (1949), la Sagrada Cena (1949) y el Descendimiento (1951).

${ }^{62}$ Era común leer cada año titulares similares en torno a las procesiones: "Después de la Cruzada ha aumentado la religiosidad del pueblo español", en portada del Odiel de 21 de abril de 1946; "Huelva dio prueba, una vez más, de su acendrado catolicismo", crónica del diario Odiel de 23 de marzo de 1948, p. 3. O artículos como "Catolicidad española", donde se reafirma el carácter católico consustancial de los españoles, publicado en la portada del Odiel de 20 de abril de 1946. También son ejemplo de ello las revistas de temática cofradiera. Revistas donde se podían leer planteamientos como este: "No cabe duda que después del azote de las guerras los pueblos se acercan más a Dios. También en Huelva se ha encendido sinceramente la religiosidad de muchos. Huelva es profundamente religiosa. Para demostrar esta cualidad, que le hace esencialmente español, el onubense tiene estos templos para su pública manifestación de fe católica" (Díaz Hierro, 1951: 21).

63 "¡Soy cristiano y español, que es ser dos veces cristiano!" diría el escritor franquista José María Pemán. Citado en Casanova Ruiz (2005: 330). 
de la recatolización ${ }^{64}$. Las cofradías eran asociaciones populares con mucho arraigo en la ciudad y componían una de las cuatro festividades más castizas y concurridas del ciclo festivo municipal, a saber las Colombinas, el Corpus, la de la Virgen de la Cinta y la Semana Santa. Crear nuevas cofradías, a la vez que se apoyaba y se hacía resucitar la fiesta después de la cuaresma y el martirio vivido en los tiempos republicanos, serviría para diversas cuestiones. En primer lugar para crear espacios sociales y ceremoniales públicos donde poder celebrar la religión y el régimen. También, para incluir en ellas un conjunto de símbolos y mensajes memorialísticos e ideológicos, de clara naturaleza nacionalcatólica fascistizada. Asimismo, a través de ellas, la jerarquía eclesiástica podía presumir de prestigio social y mostrarse como institución dominante, para lo cual había que purificar a las cofradías y publicitarlas como manifestaciones sociales de fe católica, procurando eliminar los tintes costumbristas. Por último, podían ser interesantes espacios asociativos de socialización en los valores del Nuevo Estado, una vez fue suprimido gran parte del asociacionismo civil existente. Y para ello, se intentaron organizar cofradías corporativas que agruparan a los individuos por profesiones ${ }^{65}$.

Este modelo, basado en la pretensión de fundar hermandades corporativistas, fue un propósito común en muchas localidades durante las dos primeras décadas de la dictadura. Era resultado de la lógica corporativa del régimen que tan incrustada estaba en la concepción que tanto los políticos falangistas como los católicos tenían sobre la construcción del Nuevo Estado ${ }^{66}$. Sin embar-

64 “'Recatolizar' se convirtió en una necesidad para las nuevas autoridades pues la vuelta a los valores tradicionales católicos más conservadores fue el que se mostró como mejor para la Nueva España que nacía de la guerra" (Langa Nuño, 2014: 17).

${ }^{65}$ Para un desarrollo más profundo y una caracterización socio-antropológica de las cofradías fundadas y reorganizadas en Huelva durante el período de 1937 y 1951, ver Mancha Castro (2017). A este tipo de hermandades las denominamos como "cofradías estalactitas", "puesto que las entendemos como asociaciones fruto de la proximidad de sus dirigentes a los poderes franquistas, y que fueron apoyadas -si no impulsadas- por las autoridades públicas y la jerarquía eclesiástica locales para el cumplimiento de una serie de funciones" (Mancha Castro, 2017: 153).

${ }^{66}$ Sánchez Herrero (2003) y Moreno Navarro (2006b) también reconocen esta pretensión en la fundación de algunas de las cofradías sevillanas de posguerra. Este hecho supuso "el intento más significativo de crear una cofradía sobre el modelo de las antiguas gremiales, sustituido el gremio por su cierto equivalente en ese momento: el sindicato vertical" (Moreno Navarro, 2006b: 155). "Para impulsar la fundación, renovación o mantenimiento de las hermandades y cofradías la autoridad política, a lo que no hizo ascos la autoridad eclesiástica, de 1937 a 1965, quiso que las nuevas cofradías que se fundaran o las ya existentes se unieran a los gremios o sindicatos verticales de nueva creación" (Sánchez Herrero, 2003: 302). Sánchez Garrido (2005) también ha destacado este intento en la Semana Santa de Elche. Asimismo, Vincent (2017: 103) señala que en el caso de la Semana 
go, esta pretensión fue propia sólo de los orígenes fundacionales de esas cofradías y, como demuestra la experiencia de las hermandades onubenses, rápidamente el grupo social que las compuso se diversificó por la necesidad de hacer sobrevivir la corporación. De esta manera, el intento de crear cofradías socio-profesionales, cerradas y verticales, fracasó, quedando únicamente en el vulgo -y como seña de identidad de algunas cofradías- el nombre del colectivo que dio origen a la corporación -caso de hermandades como Los Mutilados o Los Estudiantes- ${ }^{67}$.

Lo cierto es que, en la posguerra, todas las cofradías -tanto las reorganizadas como las de nueva fundación- tuvieron en sus juntas de gobierno a personas cercanas o pertenecientes a las entrañas del Movimiento local y que, por lo general, se encontraban en una cómoda posición socioeconómica, ocupando muchas de ellas diferentes puestos políticos a la misma vez que el cargo cofradiero. Asimismo, muchos jóvenes apasionados por la Semana Santa participaron en las fundaciones y en los puestos directivos. Sin embargo, la nómina de hermanos estaba compuesta por personas de todas las condiciones sociales, predominando la mediana burguesía y, sobre todo, la clase trabajadora ${ }^{68}$.

En lo referente a los liderazgos y a la regular permanencia de muchos cofrades en los cargos de gobierno de las hermandades, la realidad fue diferente según el caso. En general, en las cofradías reorganizadas no hubo problemas de dirección, no así como en aquellas que se fundaron en la posguerra -a excepción, quizá, de las cofradías de la Victoria y los Mutilados-. El resto gozó de vidas de hermandad casi inexistentes, sin cumplir una regularidad en la celebración ni de cultos internos ni de cabildos de oficiales de gobierno ${ }^{69}$. En algunos casos, el único acto a realizar era la procesión de Semana Santa y, para ello también, las ineludibles gestiones a través de las cuales conseguir los fondos necesarios para su celebración.

A partir de mediados de la década de los cuarenta, las nuevas cofradías onubenses sirvieron más claramente al proyecto de recatolización del pueblo

Santa de Valladolid, ésta "tenía un marcado tinte burgués, acentuado por un pronunciado corporativismo que reflejaba perfectamente la vida ciudadana de los primeros años del franquismo en España".

${ }^{67}$ Algo que también destaca Sánchez Garrido (2005) en el caso ilicitano.

${ }^{68}$ En palabras de Díaz Hierro (1951: 56), "en Huelva están las cofradías en poder de la clase media y modesta".

${ }^{69}$ En los libros de actas de la cofradía de los Estudiantes hay evidentes saltos en el tiempo. Del acta de una junta de gobierno del 5 de febrero de 1951 se pasa a la siguiente, que está fechada en 23 de febrero de 1954. Fernández Jurado (1997b) también señala este tipo circunstancia en otra cofradía con orígenes de carácter corporativista como fue la del Descendimiento. 


\begin{tabular}{l|l}
\hline Cofradía & Principales grupos corporativos fundadores \\
\hline La Victoria (1940/1941) & $\begin{array}{l}\text { No hay un grupo corporativo destacado. Burguesía, } \\
\text { militantes de FET }\end{array}$ \\
\hline Los Mutilados (1943) & Militares, excombatientes -mutilados o no- \\
\hline Las Tres Caídas (1944) & $\begin{array}{l}\text { No hay grupo corporativo destacado. Jóvenes cofrades, } \\
\text { militantes de FET }\end{array}$ \\
\hline La Borriquita (1947) & $\begin{array}{l}\text { Alumnos y antiguos alumnos del colegio Marista. Otros } \\
\text { jóvenes cofrades, toreros }\end{array}$ \\
\hline Los Estudiantes (1949) & $\begin{array}{l}\text { Estudiantes y profesores de segunda enseñanza, jóvenes } \\
\text { artesanos. También monárquicos, militantes de FET }\end{array}$ \\
\hline La Sagrada Cena (1949) & Funcionarios municipales de arbitrios \\
\hline El Descendimiento (1951) & Plantilla de funcionarios municipales \\
\hline
\end{tabular}

de Huelva ${ }^{70}$. Como muestra de adhesión a la sacrosanta obra nacional puesta en marcha por la dictadura franquista, al igual que venían haciendo las reorganizadas desde 1937, ofrecieron los simbólicos cargos de Hermano Mayor Honorario y Hermano Honorario tanto a instituciones públicas del régimen, como a relevantes puestos políticos y militares de la dictadura. Todas las hermandades fueron nombrando en estos cargos honoríficos al menos a un representante del poder civil, del militar y del eclesiástico.

Con la fundación de la hermandad de los caballeros Mutilados y Excombatientes en 1943 y la definitiva reorganización de la del Santo Entierro en 1944, ambas se establecieron como procesiones oficiales de la Semana Santa. En las presidencias de los cortejos de estas dos cofradías quedó representada la trinidad del poder local, conformada por el gobernador militar, el gobernador civil -que era el jefe provincial de FET y de las JONS- y el arcipreste. Con posterioridad, se unió a la oficialidad la procesión de la cofradía de los Judíos debido a su vinculación con la diputación provincial y, una vez creada la diócesis de Huelva, con el cabildo catedral. El jefe del Estado, que era Hermano Mayor Honorario de esas tres cofradías -entre otras-, presidía simbólicamen-

\footnotetext{
${ }^{70}$ Vincent (2017: 91-92) destaca que en el caso de Valladolid, "la Semana Santa desde el primer momento incluyó y sirvió a los intereses municipales y comerciales. Las liturgias de la Semana Santa ayudaron a definir un nacionalcatolicismo emergente, que proporcionó una alternativa al falangismo desde del momento mismo de la victoria. La cooperación en la revitalización de la Semana Santa del ayuntamiento, la diócesis y, en Valladolid, una institución cultural estatal como el Museo Nacional de Escultura, denotaba también una concepción de la política claramente paternalista”.
} 


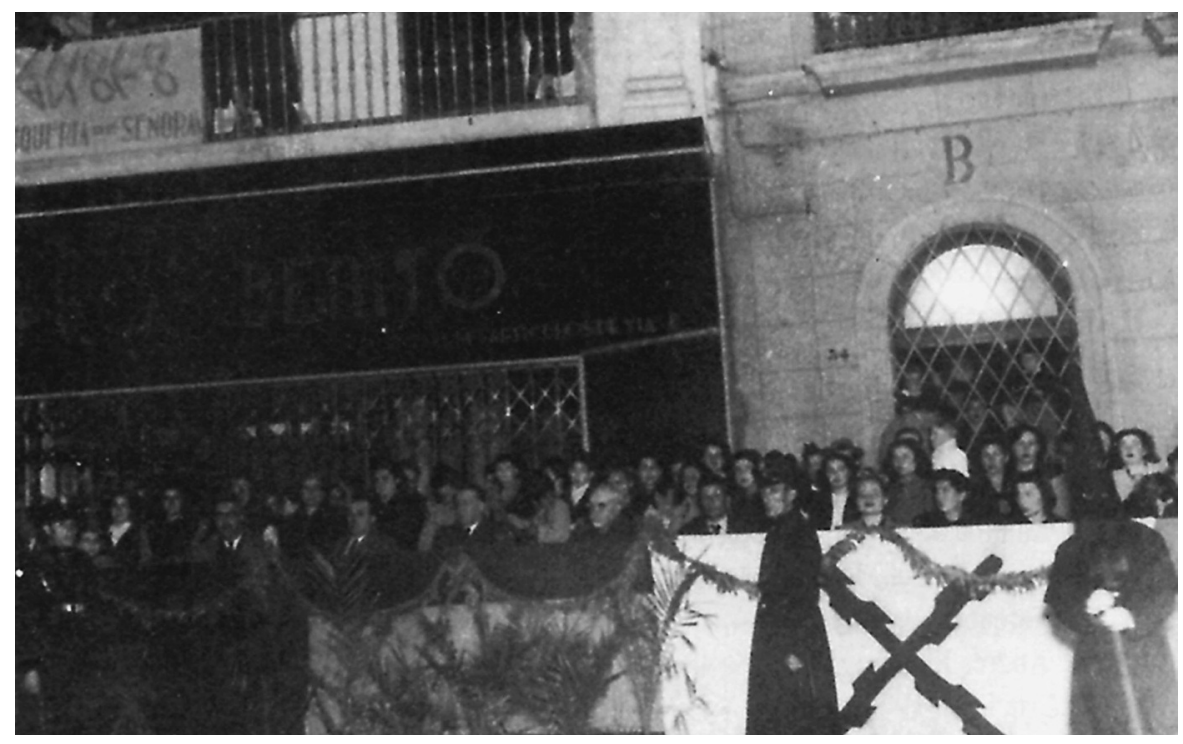

Imagen número dos ${ }^{71}$

te los tres desfiles procesionales con carácter oficial. El gobernador militar era designado para presidir en su nombre la de los Mutilados, el alcalde de la ciudad hacía lo propio con la de los Judíos y el gobernador civil era el elegido para ocupar la presidencia de la del Santo Entierro en representación de Franco. Protocolariamente, solían ser situados tras el paso de palio, antecedidos por una escuadra de soldados del Regimiento de Infantería, que escoltaba al paso. Otras autoridades como el presidente de la Comisión de Cofradías, el presidente de la audiencia provincial, los diversos tenientes de alcalde del ayuntamiento, el secretario local del Movimiento y multitud de jerarcas militares y civiles que guardaban relación con las diferentes corporaciones penitenciales, ocuparon destacados puestos en los protocolos de las cofradías, sobre todo durante el recorrido por la carrera oficial. Y la prensa local del Movimiento -el diario Odiel-se encargaba lealmente de describir con precisión todos los cargos que presidían o acompañaban los desfiles procesionales.

La población debía ver que el orden -que en el ritual quedaba simbolizado en la masiva presencia de autoridades cívico-militares- y la religiosidad cató-

${ }^{71}$ Fotografía de un tramo de la Carrera Oficial de Huelva durante la década de los cuarenta. En la misma podemos observar que la enseña de la España nacional preside una zona de autoridades, custodiada por las banderas de Falange (a la izquierda) y la cruz de Borgoña de los tradicionalistas (a la derecha). Instantánea puesta a nuestra disposición por un informante de esta investigación. 
lica ortodoxa -pretendida por el clero y vaciada de elementos espontáneos-, eran las bases que sustentaban la paz, el bienestar social y la moral de España. Al igual que en el Antiguo Régimen las hermandades con sus procesiones sirvieron para evangelizar a través de los sentidos aquellas almas a las que no llegaba la Palabra de Dios, en la España del nacionalcatolicismo volvían a ser medios adecuados para la catequesis y, sobre todo, para la dirección ideológica del pueblo ${ }^{72}$. Y en la lógica (neo)tridentina de la exaltación de los sentidos se encontró el conducto perfecto para ello, por lo que había que recuperar los modos y formas expresivas barrocas con la finalidad de atraer y fascinar a los fieles y devotos, pretendiendo identificar a la España nacionalcatólica como heredera directa de la España imperial que tanto añoraban militares y falangistas. Así, el regionalismo historicista fue sustituido como paradigma artístico y modelo estético de las cofradías y, a partir de 1939, comenzó la dictadura del neobarroco.

La estética de las cofradías que se reorganizaron y fundaron durante el primer franquismo quedó centrada en ese paradigma neobarroco que también han destacado di Febo (1988), Richards (2005), Barreiro López (2014) o Vincent (2017). Esa estética evocaba las épocas doradas y gloriosas del imperio español y al espíritu de la Contrarreforma, y despertó al socaire de una profunda transformación ideológica y un potente influjo nacionalista ${ }^{73}$. Como afirma Vincent (2017: 96 y 124): "Después de la Cruzada, el renacimiento del catolicismo [más bien diríamos, el proyecto de la recatolización] también convirtió al Barroco en un componente clave dentro de los "ritos de victoria"”, en "un vehículo cultural clave a la hora de entrelazar estos valores estéticos y políticos que estaban refundidos en un molde penitencial".

A través de la Semana Mayor vivieron en simbiosis los diferentes ritos y manifestaciones militaristas, las liturgias y las iconografías fascistas de la FET y de las JONS de los primeros años de la dictadura de Franco y las de la Iglesia católica. La presencia de FET en las procesiones no sólo se circunscribía al desfile, al que solían dotar de piquetes de escolta y de bandas de cornetas y tambores. Por medio de sus diversas organizaciones, se encargaba de asistir a multitud de actos cofradieros y engalanaba la ciudad con guirnaldas, banderas roji-

\footnotetext{
${ }^{72}$ En una reseña, publicada en la revista Lignum Crucis de 1956, sobre la intervención del canónigo Luis Pardo Gil en la Asamblea General de Cofradías de diciembre de 1955 se dice: "A las masas populares no se puede llegar con los sermones de Semana Santa por insuficiente capacidad material de los templos; es, entonces, cuando la Iglesia sale y se vuelca en las calles y pone púlpito con nuestras cofradías".

${ }^{73}$ Box Varela (2008: 176) señala que el "arte y la arquitectura estaban estrechamente interrelacionados con la política, concibiéndose como actividades propias de esta última".
} 
gualdas y diferentes colgaduras. Los pasos, a la salida y recogida en sus templos, eran recibidos y despedidos con los acordes de la 'Marcha Granadera', interpretada por las distintas bandas de música mientras los asistentes alzaban el brazo para realizar el saludo fascista, "abriendo bien la mano con el pensamiento puesto en Dios y la fe en Franco" ${ }^{\text {"4 }}$.

"Don Julio Guzmán, Arcipreste, procede a la bendición, tras de la cual se entona por la Banda Municipal el Himno Nacional, escuchado brazo en alto y en riguroso silencio. Acto seguido, se organiza la procesión de vuelta, presidida por las autoridades citadas, y formada por Directivos y Hermanos de todas las Cofradías de Huelva. El barrio presenta enorme animación, y lucen colgaduras balcones y ventanas. Al entrar la Imagen, se entona el Himno Nacional, y el público prorrumpe en estruendosa ovación que dura largo rato"75.

"La procesión se reintegró al templo a las dos de la madrugada, y a pesar de la hora avanzada, numerosísimo público se agrupó a las puertas de la iglesia para presenciar su entrada. Al igual que a la salida la Banda de Música interpretó el Himno Nacional que fue escuchado en medio de un gran silencio y brazo en alto"76.

El saludo a la romana sería prohibido por el cardenal Segura en la archidiócesis de Sevilla en el año 1944 (Navarro de la Fuente, 2014), siendo un ejemplo manifiesto de la tensión generada por esta mezcolanza de lenguajes, símbolos y liturgias ${ }^{77}$. La jerarquía eclesiástica, buscando profundizar en la ortodoxia religiosa que entendía debía impregnar las procesiones de Semana Santa, procuraría eliminar esa fusión entre los símbolos católicos y los fascistas falangistas. La Cruzada ya había concluido años atrás con la Victoria y su sagrada celebración debía ser clausurada. Jerarcas católicos, como el arzobispo Pedro Segura o el arcipreste Julio Guzmán, se centraron, a partir de ese momento, en purificar el ritual. Para ello se creó en 1945 la Comisión de Cofradías, brazo ejecutor mediante el cual la autoridad eclesiástica controlaría a las hermandades y con el que regularizaría la celebración de la Semana Santa:

${ }^{74}$ Con estas palabras lo pedía el alcalde, Joaquín González Barba, en su discurso por el fin de la guerra, publicado en el diario Odiel de 29 de marzo de 1939, p. 2.

${ }^{75}$ Fragmento de la crónica del acto de bendición de la Virgen del Mayor Dolor, celebrado en la plaza de San Francisco. Odiel de 12 de abril de 1938, p. 5.

${ }^{76}$ Reseña de la recogida de la procesión de la cofradía de San Francisco que hace el diario Odiel el 21 de marzo de 1940, p. 6.

77 Como señala Hernández Burgos (2011: 291) para el caso granadino, "la Semana Santa se convirtió en un campo de lucha simbólica muy importante entre los distintos componentes del Estado franquista, que no dudaron en pugnar por imponer sus ideas y dotar de contenido a la festividad". 


\begin{abstract}
"Será objeto de una vigilancia especial por esta Comisión de Cofradías, cuanto a las ordenanzas dichas se dispone sobre el comportamiento de los hermanos fuera y dentro de la procesión, las paradas injustificadas de los 'pasos' todo cuanto particularmente, colectiva o individualmente, desdiga de la seriedad, piedad y espíritu de penitencia que han de informar las manifestaciones de culto público, como son estas procesiones de Hermandades, en días tan santos"78.

"No; la Semana Santa no es un festejo más dentro de la nomenclatura festera de cualquier localidad; ni las procesiones cofradieras tienen nada que ver con las expansiones del jolgorio. No es respetuoso, e incluso se hace repulsivo [...], que las imágenes de los Cristos y Dolorosas -tan sagradas y dignas de veneración por lo que nos recuerdan y representan- aparezcan en medio de una turba confusa de cantadores y vociferadores"79.
\end{abstract}

\title{
5. Conclusiones
}

Las procesiones de Semana Santa de la posguerra fueron una gran obra de teatro social, político y religioso, intensamente controlada y dirigida por los poderes franquistas, en la que se representaron en comunión pública todos los elementos que componían el Movimiento Nacional. Desde el clero y la jerarquía de la Iglesia local hasta los cargos militares, pasando por los puestos políticos municipales y provinciales que se repartían falangistas, tradicionalistas carlistas, monárquicos alfonsinos y católicos rendidos a la causa franquista. La Semana Santa de la posguerra se convirtió en un fenómeno radicalmente transformado y engrandecido, bajo el que se canalizó el discurso ideológico oficial de la integrista Iglesia católica del momento y el Nuevo Estado nacionalista, y en el que se mostraba, de cara a la población, su particular unión, que debía ser símbolo de victoria, paz y orden.

A través de la Semana Mayor onubense, las autoridades políticas y militares locales buscaron popularizar, legitimar, bendecir y sacralizar sus actuaciones: el alzamiento, la represión y la dictadura; y articularon en torno a ella un discurso de exaltado catolicismo y nacionalismo español mitificado. Asimismo, se presentaron como garantes de su celebración, recordando, constantemente

\footnotetext{
${ }^{78}$ Extracto de las normas publicadas por el arcipreste de Huelva en el Odiel de 30 de marzo de 1947, p. 2.

${ }^{79}$ Fragmento del artículo titulado 'Glosa y derivaciones de una nota del Obispado'. Publicado en las páginas del diario Odiel del 2 de abril de 1955, p. 4, y firmado por el periodista Domingo Gómez Flery. En ese artículo podíamos leer más acerca de unas directrices emanadas de los poderes eclesiásticos y que fueron proporcionadas a los directivos de las cofradías de Semana Santa. Estas directrices instaban a mantener el orden, la solemnidad y el espíritu de ascetismo y penitencia en las procesiones, así como a cumplir con los horarios y otras medidas previsoras bajo pena de sanción.
} 
por la prensa, el calvario al que la fiesta fue sometida durante los años republicanos y la martirización del patrimonio de las cofradías llevado a cabo por las "turbas ateas" en los "días de devastación marxista" 80 . Es decir, a través de la Semana Santa, los poderes políticos fueron construyendo multitud de discursos y memorias sobre la guerra y la dictadura que resignificaron los símbolos religiosos populares, ahondando en la patrimonialización de la fiesta y dotándola de significados políticos que la ligaron fuertemente a los valores nacionalcatólicos, contrarrevolucionarios y monárquicos, y que -al menos hasta 1944la inundaron de prácticas rituales fascistizadas.

En principio, la jerarquía católica ratificó y amparó los mensajes políticos que se deslizaban en torno a la Semana Santa y las cofradías pero, poco a poco, sobre todo a partir de 1944, pretendió reducir su significación al de un ritual celebrado bajo directrices católicas ortodoxas, buscando su pureza religiosa. Los saludos a la romana fueron cortados de raíz en las procesiones a mediados de la década de los cuarenta. Por su parte, los comportamientos espontáneos eran advertidos por medio de notas de prensa, que instaban a que no se realizasen actos indecorosos bajo pena de ser sancionados. Sin embargo, la jerarquía eclesiástica jamás censuró la vanidosa exhibición de autoridades civiles y militares en esas piadosas y penitenciales procesiones que anhelaba.

Ambas visiones vivieron en simbiosis durante todo el primer franquismo, dando lugar a un modelo festivo mixtificado, fuertemente patrimonializado y altamente controlado y canalizado por los poderes establecidos. Un ritual que proporcionaba diferentes espacios socio-simbólicos, celebrativos, públicos, en los que se podía -y debía- ritualizar la adhesión a los valores nacionalcatólicos -que, hasta mediados de los cuarenta, se presentaron con evidentes rasgos de fascistización-, a modo de ritos de legitimación popular de la dictadura. Un sincrético fenómeno colectivo -de naturaleza simbólica-, sociopolítico y religioso al mismo tiempo, en el que se expresaba a la perfección la compleja y mestiza naturaleza política del régimen.

\section{Bibliografía}

ABADES, Jesús y CABACO, Sergio (2009). La imaginería de la Semana Santa de Huelva destruida en 1936. Carrera Oficial. Revista independiente de la Semana Santa, 6, $62-65$.

ÁLVAREZ REY, Leandro; RUIZ SÁNCHEZ, José Leonardo (1990). Huelva durante la II República: partidos, elecciones y comportamiento político (1931-1936). Huelva

${ }^{80}$ Este tipo de referencia a los republicanos sería una constante en las publicaciones de prensa y revistas cofradieras del primer franquismo. 
en su historia, 3, 603-670. <https://idus.us.es/xmlui/bitstream/handle/11441/285 28/huelva_durante_segunda_republica.pdf?sequence=1\&isAllowed=y>

BARREIRO LÓPEZ, Paula (2014). Reinterpreting the Past. The Baroque Phantom during Francoism. Bulletin of Spanish Studies, vol. 91, n. 5, 715-734. <https://doi.org/10.1080/14753820.2014.908566>

BOX VARELA, Zira (2008). La fundación de un régimen. La construcción simbólica del franquismo. Tesis doctoral para la obtención del grado de doctor, Facultad de Ciencias Políticas y Sociología, Universidad Complutense de Madrid, Madrid, España. <http://eprints.ucm.es/8572/1/T30783.pdf>

BRENAN, Gerald (1996). El laberinto español. Antecedentes sociales y políticos de la guerra civil. Barcelona: Plaza y Janés.

CARR, Raymond (2009). España 1808-2008 (2a ed.). Barcelona: Ariel.

CASANOVA RUIZ, Julián (2005). La Iglesia de Franco (2a ed.). Barcelona: Crítica.

CASANOVA RUIZ, Julián (2014). España partida en dos. Breve historia de la Guerra Civil española ( $6^{\mathrm{a}}$ ed.). Barcelona: Crítica.

CHAVES NOGALES, Manuel (2013). Semana Santa en Sevilla. Córdoba: Editorial Almuzara.

CORDERO OLIVERO, Inmaculada (1997). Huelva durante la Guerra Civil: las celebraciones públicas. Huelva en su historia, 6, 137-154. <http://www.uhu.es/publica ciones/ojs/index.php/huelvahistoria/article/view/868/1365>

DE LA CUEVA MERINO, Julio (1998). El anticlericalismo en la Segunda República y la Guerra Civil. En Emilio LA PARRA LÓPEZ y Manuel SUÁREZ CORTINA (Eds.), El anticlericalismo español contemporáneo (211-301). Madrid: Biblioteca Nueva.

DE LA CUEVA MERINO, Julio (2014). El laicismo republicano: tolerancia e intolerancia religiosa en la Segunda República española. Mélanges de la Casa de Velázquez, 44-1, 89-109. <http://journals.openedition.org/mcv/5515>

DELGADO RUIZ, Manuel (1989). La antirreligiosidad popular en España. En María Jesús BUXÓ REY, Salvador RODRÍGUEZ BECERRA y León Carlos ÁLVAREZ Y SANTALÓ (Coords.), La religiosidad popular (499-514), vol. 1. Barcelona: Anthropos.

DELGADO RUIZ, Manuel (1992). La ira sagrada. Anticlericalismo, iconoclastia y antirritualismo en la España contemporánea. Barcelona: Humanidades.

DELGADO RUIZ, Manuel (1997a). Anticlericalismo, espacio y poder. La destrucción de los rituales católicos, 1931-1939. Ayer. Revista de Historia Contemporánea, 27, 149-180.

DELGADO RUIZ, Manuel (1997b). La iconoclastia como violencia corporal en las sociedades mediterráneas. En Francisco CHECA Y OLMOS y Pedro MOLINA (Eds.), La función simbólica de los ritos. Rituales y simbolismo en el Mediterráneo (367-398). Almería y Barcelona: Institutos de Estudios Almerienses e Icaria.

DELGADO RUIZ, Manuel (2001). Luces iconoclastas. Anticlericalismo, espacio y ritual en la España contemporánea. Barcelona: Ariel.

DELGADO RUIZ, Manuel (2005). Violencia anticlerical e iconoclasta en la España contemporánea. En José Luis LEDESMA VERA, Javier MUÑOZ SORO y Javier RODRI- 
GO (Coords.), Culturas y políticas de la violencia. España siglo XX (75-100). Madrid: Siete Mares.

DI FEBO, Giuliana (1988). La santa de la raza. Un culto barroco en la España franquista. Barcelona: Icaria.

DI FEBO, Giuliana (2016). Franco y el nacionalcatolicismo: la construcción del carisma religioso. En Enrique MORADIELLOS GARCÍA (Dir.), Las caras de Franco. Una revisión histórica del caudillo y su régimen (133-161). Madrid: Siglo XXI.

DÍAZ HIERRO, Diego (1951). Huelva Sagrada. Huelva: Imprenta Antonio Plata.

DOMENE VERDÚ, José Fernando (2017). La función social e ideológica de las fiestas religiosas: identidad local, control social e instrumento de dominación. Revista de Dialectología y Tradiciones Populares, vol. 72, n. 1, pp. 171-197.

<https://doi.org/10.3989/rdtp.2017.01.007>

ESPINOSA MAESTRE, Francisco (2005). La Guerra Civil en Huelva (4ª ed.). Huelva: Diputación provincial de Huelva.

ESPINOSA MAESTRE, Francisco y GARCÍA MÁRQUEZ, José María (2009). La desinfección del solar patrio: la represión judicial militar: Huelva (1936-1945). En Mirta NÚÑEZ DÍAZ-BALART (Coord.), La gran represión. (283-429). Barcelona: Flor del Viento Ediciones.

FERIA VÁZQUEZ, Pedro Jesús (2016). La represión económica en Huelva durante la Guerra Civil y la Posguerra. Huelva: Diputación de Huelva.

FERNÁNDEZ JURADO, Jesús (1997a). Huelva Cofrade. Historia de la Semana Santa de Huelva y su Provincia. Tomo I. Sevilla: Ediciones Tartessos.

FERNÁNDEZ JURADO, Jesús (1997b). Huelva Cofrade. Historia de la Semana Santa de Huelva y su Provincia. Tomo II. Sevilla: Ediciones Tartessos.

GARCÍA DÍAZ, Miguel Ángel (2004). Vieja y nueva política. Huelva bajo el régimen de Primo de Rivera (1923-1930). Huelva: Ayuntamiento de Huelva.

GENTILE, Emilio (2004). La sacralización de la política y el fascismo. En Susana SUEIRO SEOANE (Coord.); Javier TUSELL GÓMEZ; Emilio GENTILE; Giuliana DI FEBO (Eds.), Fascismo y franquismo cara a cara. Una perspectiva histórica (5768). Madrid: Biblioteca Nueva.

HERNÁNDEZ BURGOS, Claudio (2011). Granada Azul. La construcción de la "Cultura de la Victoria" en el primer franquismo. Granada: Comares.

HERNÁNDEZ BURGOS, Claudio (2016). De la cultura de guerra a la cultura de la victoria: los vencedores y la construcción de la dictadura franquista (1936-1951). Pasado y Memoria: Revista de Historia Contemporánea, 15, 123-148. <https://doi. org/10.14198/PASADO2016.15.05>

HOBSBAWN, Eric (2002). Introducción: La invención de la tradición. En Eric HOBSBAWN y Terence RANGER (Eds.), La invención de la tradición (7-21). Barcelona: Crítica. <http://www.saladehistoria.com/Biblioteca_Digital/pdf/H1983Tradicion. pdf>

HURTADO SÁNCHEZ, José (2000). Cofradías y poderes. Relaciones y conflictos. Sevilla, 1939-1999. Sevilla: Editorial Castillejo. 
LA PARRA LÓPEZ, Emilio y SUÁREZ CORTINA, Manuel (Eds.) (1998). El anticlericalismo español contemporáneo (211-301). Madrid: Biblioteca Nueva.

LANGA NUÑO, Concepción (2014). "De Sevilla la roja a la Tierra de María Santísima": la "recatolización" de Sevilla. En José Leonardo RUIZ SÁNCHEZ (Coord.), La Iglesia en Andalucía durante la Guerra Civil y el primer franquismo (15-47). Sevilla: Secretariado de publicaciones Universidad de Sevilla.

MANCHA CASTRO, José Carlos (2017). Cofradías y poderes políticos. Una aproximación a las hermandades de Semana Santa en la Huelva del primer franquismo. Revista Andaluza de Antropología, 13, 140-163. <http://www.revistaandaluzadean tropologia.org/uploads/raa/n13/mancha.pdf>

MORADIELLOS GARCÍA, Emilio (2016). Caudillo de España. Franco, un dictador soberano y carismático. En Emilio MORADIELLOS GARCÍA (Dir.), Las caras de Franco. Una revisión histórica del caudillo y su régimen (29-95). Madrid: Siglo XXI.

MORENO NAVARRO, Isidoro (1999). Las Hermandades andaluzas: una aproximación desde la Antropología (2 $2^{\mathrm{a}}$ ed.). Sevilla: Secretariado de publicaciones Universidad de Sevilla.

MORENO NAVARRO, Isidoro (2006a). La Semana Santa de Huelva. En Esther FERNÁNDEZ DE PAZ (Dir.), Artes y Artesanías de la Semana Santa Andaluza. Vol. 1. La Semana Santa como Patrimonio Cultural de Andalucía (252-289). Sevilla: Ediciones Tartessos.

MORENO NAVARRO, Isidoro (2006b). La Semana Santa de Sevilla. Conformación, mixtificación y significaciones ( $5^{\mathrm{a}} \mathrm{ed}$.). Sevilla: Biblioteca de Temas Sevillanos.

MORENO NAVARRO, Isidoro y AGUDO TORRICO, Juan (2012). Las fiestas andaluzas. En Isidoro MORENO NAVARRO; Juan AGUDO TORRICO (coords.). Expresiones culturales andaluzas (165-218). Sevilla: Aconcagua libros.

NAVARRO DE LA FUENTE, Santiago (2014). La religiosidad popular como elemento de adhesión al primer franquismo. Una aproximación al caso de Sevilla. En José Leonardo RUIZ SÁNCHEZ (Coord.), La Iglesia en Andalucía durante la Guerra Civil y el primer franquismo (109-126). Sevilla: Secretariado de publicaciones Universidad de Sevilla.

ORDÓÑEZ MÁRQUEZ, Juan (1968). La apostasía de las masas y la persecución religiosa en la provincia de Huelva 1931-1936. Madrid: C.S.I.C.

RAGUER SUÑER, Hilari (2010). La memoria histórica de la Iglesia. Pliegos de Yuste revista de cultura y pensamiento europeos, 11-12, 47-54. <http://www.pliegosdeyus te.eu/n1112pliegos/pdfs/47-56.pdf>

RICHARDS, Michael (2005). "Presenting arms to the Blessed Sacrament": Civil War and Semana Santa in the city of Málaga, 1936-9. En Chris EALHAM y Michael RICHARDS (Coords.), The Splintering of Spain: Cultural History and Spanish Civil War, 1936-9 (196-222). Cambridge: CUP.

RINA SIMÓN, César (2015). Los imaginarios franquistas y la religiosidad popular (19361949). Badajoz: Diputación de Badajoz. 
RINA SIMÓN, César (2016). Rituales de pasión, muerte y resurrección. La religiosidad popular y la legitimidad sagrada en el franquismo. En Francisco COBO ROMERO, Claudio HERNÁNDEZ BURGOS y Miguel Ángel DEL ARCO BLANCO (Coords.), Fascismo y modernismo: política y cultura en la Europa entreguerras (1918-1945) (171-184). Granada: Comares.

RODRIGO, Javier (2014). Guerreros y teólogos. Guerra santa y martirio fascista en la literatura de la cruzada del 36. Hispania. Revista Española de Historia, vol. 74, n. 247, 555-586. <https://doi.org/10.3989/hispania.2014.v74.i247>

RODRÍGUEZ BECERRA, Salvador (1985). Las fiestas de Andalucía. Sevilla: Editoriales Andaluzas Unidas.

RODRÍGUEZ MATEOS, Joaquín (1998). La ciudad recreada. Estructura, Valores y Símbolos de las Hermandades y Cofradías de Sevilla. Sevilla: Diputación de Sevilla.

SÁNCHEZ GARRIDO, Roberto (2005). Los significados de la fiesta. El nacimiento de una cofradía de Semana Santa. Gazeta de Antropología, 21. [Versión electrónica]. <http://www.ugr.es/ pwlac/G21_15Roberto_Sanchez_Garrido.html>

SÁNCHEZ HERRERO, José (2003). La Semana Santa de Sevilla. Madrid: Sílex.

SAZ CAMPOS, Ismael (2003). España contra España. Los nacionalismos franquistas. Madrid: Marcial Pons.

SAZ CAMPOS, Ismael (2012). Franco, ¿caudillo fascista? Sobre las sucesivas y contradictorias concepciones falangistas del caudillaje franquista. Historia y Política, 27, 27-50. <http://www.cepc.gob.es/publicaciones/revistas/revistaselectronicas? IDR $=9 \&$ IDN $=605 \&$ IDA $=38>$

SUGRAÑES GÓMEZ, Eduardo Jesús (1988). La Unión de Cofradías de Huelva (Recorrido histórico por el movimiento asociativo de las hermandades de penitencia). Huelva: Imprenta Huelva Ilustrada.

SUGRAÑES GÓMEZ, Eduardo Jesús (1998). Historia de la Semana Santa de Huelva ( $2^{a}$ ed.). Huelva: Fundación El Monte.

THOMÀS ANDREU, Joan Maria (2001). La Falange de Franco. Fascismo y fascistización en el régimen franquista: (1937-1945). Barcelona: Plaza y Janés.

THOMÀS ANDREU, Joan Maria (2016). Franquistas contra franquistas. Luchas por el poder en la cúpula del régimen de Franco. Barcelona: Debate.

TURNER, Victor (1980). La selva de los símbolos. Madrid: Siglo XXI.

TURNER, Victor (1988). El proceso ritual. Estructura y antiestructura. Madrid: Taurus.

VINCENT, Mary (2017). La Semana Santa en el nacionalcatolicismo: espacio urbano, arte e historia. El caso de Valladolid (1939-1949). Historia y Política, 38, 91-127. <https://doi.org/10.18042/hp.38.04> 